\title{
ENERGIZING THROUGH VISUALS: HOW SOCIAL ENTREPRENEURS USE EMOTION- SYMBOLIC WORK FOR SOCIAL CHANGE
}

\author{
David Barberá-Tomás \\ Associate Professor \\ INGENIO (CSIC-UPV), Universitat Politècnica de València, \\ Camino de Vera s/n, 46022 Valencia, España \\ Email: jobarto@ingenio.upv.es \\ Itziar Castelló \\ Senior Lecturer of Digital Economy \\ Surrey Business School, Rik Medlik Building \\ University of Surrey, Guildford, Surrey, GU2 7XH, UK \\ Email: i.castello@ surrey.ac.uk
}

\author{
Frank G. A. de Bakker \\ Professor of Corporate Social Responsibility \\ IESEG School of Management \\ 3 rue de la Digue, 59000 Lille, France \\ $\&$ \\ LEM-CNRS 9221, 59000 Lille, France \\ Email: f.debakker@ieseg.fr
}

\section{Charlene Zietsma}

Associate Professor of Management

Room 416 Business Building

Smeal College of Business

Penn State University

University Park, PA 16802

Email: czietsma@psu.edu 


\begin{abstract}
We know little about how social entrepreneurs try to induce enactment of their cause, especially when this cause is difficult to embrace. Through a longitudinal study, we analyze how anti-plastic pollution social entrepreneurs use multimodal (visual and verbal) interactions to influence their targets and promote their cause. Our findings reveal that these social entrepreneurs used what we call emotion-symbolic work, which involved using visuals and words to elicit negative emotions through moral shock, and then transforming those emotions into emotional energy for enactment. The emotional transformation process entailed connecting target actors to a cause, a collective identity and the social entrepreneurs themselves. The exploration of emotion-symbolic work offers new ways of seeing by emphasizing the use of multimodal interactions to affect emotions in efforts to influence target actors to enact a cause.
\end{abstract}

\title{
INTRODUCTION
}

Social entrepreneurship is "innovative, social value creating activity that can occur within or across the nonprofit, business, or government sectors" (Austin, Stevenson \& Wei-Skillern, 2006: 2). Social entrepreneurs ${ }^{1}$ seeking to change systems and behaviors to achieve socially beneficial outcomes must gain attention and support for their causes. To make true change, they must influence people to identify with their cause and to enact it in their daily lives (Rao \& Giorgi,

\footnotetext{
${ }^{1}$ We focus this paper on social entrepreneurs as people who try to make social change. Standard definitions of social entrepreneurship include the proviso that social entrepreneurs use market-based methods to do so (e.g., Grimes, et al., 2013). The phenomenon we focus on, however, is that of persuading others to support and enact one's change process. As such, it is sufficiently general that it applies to institutional entrepreneurs (DiMaggio, 1988), leaders of social movements (Kaplan, 2008), business executives and managers (Hambrick \& Lovelace, 2018), political leaders (Allison, 1971), religious organizations (Tracey, 2016), cultural entrepreneurs (Jennings, Edwards, Jennings \& Delbridge, 2015; Lounsbury \& Glynn, 2001) and indeed, anyone seeking to stimulate collective action to make any sort of change. We return to this point in the discussion section.
} 
2006). This is particularly important when targeted supporters must be persuaded that their own behavior is "wrong" and that they should change it, often in ways that are uncomfortable, difficult and deviant relative to their social programming. For example, animal rights movement entrepreneurs who try to influence people to stop eating meat often require targeted supporters to stop institutionalized behaviors: meat is culturally embedded, taken-for-granted, and enjoyed by many who do not want to give it up; people are even socially sanctioned for being vegan (Delmestri \& Goodrick, 2016). To embrace the "cause" involves accepting guilt for past behavior.

To gain engaged adherents that enact their causes (i.e., adherents who change their moral principles regarding an issue and then put those principles into action), social entrepreneurs must attract attention to disrupt valued and taken-for-granted norms and practices. Some work has studied the use of dramatic visuals related to climate change and humanitarian causes to attract the attention of potential supporters (Mortensen, Allan \& Peters, 2017; O’Neill \& Smith, 2014), such as the photo of the Syrian refugee boy lying dead on the beach (Fehrenbach \& Rodogno, 2015). Similarly, social movement scholars have shown that movement entrepreneurs sometimes use visual images (Doerr, Mattoni \& Teune, 2013; Wettergren, 2005) to elicit 'moral shock', 'the vertiginous feeling that results when an event or information shows that the world is not what one had expected, which can sometimes lead to articulation or rethinking of moral principles" (Jasper, 2011: 287), to convert apathetic bystanders into social movement supporters (Jasper, 2011; Jasper $\&$ Poulsen, 1995). Yet research reveals a tension: while visuals eliciting moral shock may attract attention, they may also have negative consequences: alienating supporters (Scheff, 2007), or stimulating denial or avoidance of a cause (O’Neill \& Nicholson-Cole, 2009).

This is particularly likely to be the case when the cause requires potential supporters to face "the error of their ways", inducing guilt. Defensiveness, denial and aggression are natural 
responses to intense feelings of guilt (Tangney \& Dearing, 2003), yet if potential supporters must change their behavior to enact the cause, some critique of past behavior seems necessary. Although the role of emotions in social movement organizations has been studied before (Aminzade \& McAdam, 2002; Eyerman, 2005; Goodwin \& Jasper, 2006; Jarvis, Goodrick \& Hudson, forthcoming), we know little about the process by which social entrepreneurs can deal with or get beyond negative emotions to convince targeted supporters to enact their cause and support their organizations, even when doing so is difficult. As Jasper (2008: 106) noted, "responses to moral shocks vary greatly. Most people, in most cases, resign themselves to unpleasant changes... But others, through complex emotional processes that few researchers have described, channel their... anger into... individual and collective... activity".

To address this issue, our research question focused on how social entrepreneurs use visual images and textual interactions to influence their targets to enact a difficult cause. We present an inductive, longitudinal study of the efforts of social entrepreneurs to convince targets not only that they are responsible for plastic pollution, but also that they should join with the social entrepreneurs' organization to refuse, rather than recycle plastics, exchanging highly convenient and taken-for-granted behavior for new and often less comfortable ways of living. Through a qualitative analysis of various data (including an extensive collection of publicly available social media interactions), we present findings that reveal how social entrepreneurs used what we call emotion-symbolic work, using visual images to evoke strong negative emotions of moral shock including rage, sadness and despair - among targeted actors to draw attention to the issue of plastic pollution. In public interactions, they then transformed and directed those strong emotions into emotional energy that fueled their targets' enactment of the social entrepreneurs' cause.

The emotion-symbolic work process revealed in our findings brings attention to two under- 
researched areas in social entrepreneurship and social-symbolic work more generally: first, entrepreneurs' use of visual images (Boxenbaum, Jones, Meyer \& Svejenova, 2018; Doerr et al., 2013; Meyer, Höllerer, Jancsary \& Van Leeuwen, 2013), and second, the manipulation of emotions (Hiatt, Sine \& Tolbert, 2009; Jasper \& Poulsen, 1995; Tracey, 2016), to convert targets into active supporters (Eyerman, 2005). Our findings contribute to a better understanding of how social entrepreneurs manage emotions to encourage target actors to enact a cause when that cause is difficult to embrace. We identify a multimodal (that is, including both verbal and visual elements) emotional transformation process that converts the moral shock elicited by visual images into emotional energy, comprised of energetic arousal, identification and moral emotions. The emotional energy fuels the enactment of the cause, resolving the tension identified in prior work on visual images between attracting attention and potentially alienating supporters (Mortensen et al., 2017; O'Neill \& Nicholson-Cole, 2009). We refer to the activities we noted in our study as "emotion-symbolic work", since they combine emotion work ("making a conscious, intended try at altering feeling", Hochschild, 1979: 560), with symbolic work, which involves meaning making that is "constituted through language and other symbolic expression" (Phillips \& Lawrence, 2012: 224). We argue that emotion-symbolic work offers a new way of seeing by emphasizing the use of visual images along with verbal interactions to influence target actors' emotions and actions, which has broad application in management as well as other disciplines (Giorgi, 2017; Hambrick \& Lovelace, 2018; Tracey, 2016). Social entrepreneurs play a key role in such work.

\section{LITERATURE REVIEW}

\section{Emotions in Entrepreneurship and Social Entrepreneurship}

Most studies of emotions and entrepreneurship have focused exclusively on the emotions of the entrepreneur (Cardon, Foo, Shepherd \& Wiklund, 2012; Jennings, Edwards, Jennings, 
Delbridge., 2015), describing, for example, how entrepreneurial passion motivates or affects different stages of the entrepreneurial process (Cardon, Zietsma, Saparito, Matherne \& Davis, 2005; Chen, Yao \& Kotha, 2009). In the case of social entrepreneurship, compassion (Miller, Grimes, McMullen \& Vogus, 2012; Shepherd \& Williams, 2014) and empathy (Bacq \& Alt, 2018; Mair \& Noboa, 2006) are significant motivating feelings, although Arend (2013) made the case for greater attention to drivers of emotions and the role they play in entrepreneurship. These articles all focus on how entrepreneurs' emotions affect decisions to create organizations to pursue social value (Mair \& Noboa, 2006).

Less work has focused on how entrepreneurs elicit the emotions of other actors. Studies of conventional entrepreneurship have suggested that entrepreneurs' expressed emotions may impact resource providers. For example, entrepreneurs' expressed passion has been found to influence investors' investment decisions (Cardon, Glauser \& Murnieks, 2017; Chen et al., 2009). Some work has also shown entrepreneurs' deliberate attempts to elicit emotions among audiences. For example, Clarke (2011: 1383) found that entrepreneurs manipulated visual symbols such as office décor "to ensure stakeholders [in this case, investors] developed positive emotions in relation to the venture", while Jennings et al. (2015) showed how entrepreneurs' dramatic performances and material symbols (scale models of yachts) aroused stakeholders' emotions and identification with an entrepreneurial project. Similarly, Massa, Helms, Voronov and Wang (2017) showed how coolclimate wineries crafted rituals to inspire emotional experiences among audience members, who then evangelized the wine to others.

A limited body of research, mostly in the social movement literature, has focused on how social entrepreneurs use emotions to affect their audiences. This lacuna is curious since, as Moon (2013: 291) has eloquently described, "emotions do not simply lurk beneath the surface of, or arise in 
response to, 'real' processes of social change - they drive them, impede them, shape them, and furthermore, in some situations, they constitute the substance of social power". Emotions are a key component of collective action (Aminzade \& McAdam 2002; Goodwin, Jasper \& Polletta 2001; Jasper 2011; Taylor \& Rupp 2002), and are often used in practice by social entrepreneurs to mobilize potential supporters. Positive emotions are also a key means of facilitating enactment of a cause (Eyerman, 2005; Polletta \& Jasper, 2001), particularly when a movement's collective identity emotionally resonates with activists (Rao, Morrill \& Zald, 2000; Staggenborg, 2013).

Yet displays of emotion by activists and social entrepreneurs can be stigmatized, particularly when they are in support of causes that may be perceived as fringe or counter-normative, such as animal rights (Jarvis, et al., forthcoming). Further, "strong emotions, such as moral outrage" may not be enough to motivate action (Reger, 2004: 206), and negative emotions may have paradoxical effects. Studies of responses to climate change appeals question the extent to which negative emotions should be intentionally elicited in audiences, given that they can cause "denial, apathy, avoidance, and negative associations that may come as a result of coping with any unpleasant feelings evoked" (O’Neill \& Nicholson-Cole, 2009: 376).

Despite the importance of emotions to social entrepreneurship, both in attracting potential supporters, and getting them to act in support of the cause, there is very limited work in the social entrepreneurship literature that focuses on how emotions are elicited in audiences. One common means of eliciting emotions is through the use of visual images.

\section{The Use of Visual Images in Causes for Social Change}

Activists endeavoring to gain support for their causes have long used visual symbols to elicit emotions, attract attention and persuade potential supporters (Christensen, 2018; Doerr et al., 2013; Jasper \& Poulsen, 1995; McLaren, 2013; Zott \& Huy, 2007). Such social influence tasks are also 
important within organizations, as executives, for example, use symbols to influence organization members to support new strategic themes (Hambrick \& Lovelace, 2018). Yet surprisingly, the use of visual images to gain support is understudied, particularly in the management literature (Boxenbaum et al., 2018; Lefsrud, Graves \& Phillips, 2015; Meyer et al., 2013; Meyer, Jancsary, Höllerer \& Boxenbaum, 2018), and is nearly absent in the social entrepreneurship literature, which is curious since the emotion-evoking nature of images would appear to make them particularly apt for influencing people's commitment to social causes.

Visuals images may be both particularly evocative of emotions, and particularly able to stimulate reflexivity (Wagner-Lawlor, 2016). They create a situated perspective, making the message a visual symbol conveys personally relevant to the viewer (Kress \& van Leeuwen, 2006; Meyer et al., 2018). Visual symbols are often used metaphorically, communicating quickly in a gestalt (Langer, 1951), and in a way that elicits visceral, embodied and emotional responses (Meyer et al., 2018). Together, these characteristics of visual images enable them "to generate an immediate and powerful impact that surpasses a purely cognitive processing of its content, whereby audiences become engaged affectively, aesthetically, and corporeally" (Meyer et al., 2018: 395). Visual images are particularly useful in capturing attention and stimulating responses when ideas and issues do not fit with established understandings, and when the producer of the visual image is not prominent, known or legitimate to the viewer (Meyer et al., 2018).

While visual images may be interpreted differently by audiences with different social programming (Meyer et al., 2018), they are often designed to make you feel a particular way (Meyer et al., 2013): "Even if visual meaning appears so self-evident as to be 'naturally' given, this is simply a product of the visual being so widely distributed and understood within a culture that it is no longer recognized as being socially constructed" (O’Neill \& Smith, 2014: 74). When 
activists use visual images, they are often attempting to both attract supporters' attention to their organization and to mobilize their enactment of a particular cause.

Yet using visual images also has potential downsides. Studies of attempts to influence responses to climate change show that issue salience can be increased by impactful visuals, but that such visuals often depress people's efficacy about being able to act on the issue (O'Neill \& Nicholson-Cole, 2009; O'Neill \& Smith, 2014). Visuals also may make viewers think of the problem in the past, or normalize the issue, particularly with repeated presentation. Supporter "fatigue" may ensue with repeated exposure to images like the one of the Syrian boy lying dead on the beach (Mortensen et al., 2017), and they may fail to elicit action. Thus, the presentation of visuals alone, without careful attention to how they impact audiences, may create only fleeting attention, and even less enactment of a cause. O'Neill and Nicholson-Cole (2009) suggested using evocative images with other kinds of representations in multimodal discourse.

\section{Multimodal Discourse}

Heeding these warnings, textual discourse to accompany visual images may be necessary to guide interpretations. As Nisbet (2009) noted, it is not just visual symbols that matter, but also the frames with which they are used. Thus, multimodality is important to study since visuals and text together are key resources to give sense to audiences (Höllerer, Jancsary \& Grafström, 2018; Zamparini \& Lurati, 2012). "Multimodal compositions enhance representation, theorization, resonance, and perceived validity of narratives" (Höllerer et al., 2018: 617).

Meyer et al. (2018), in a recent theoretical contribution, have argued that visual vs. verbal texts have different semiotic features which provide different affordances, and thus can be used in different ways in institutionalization projects. Verbal texts are strongly bound in conventions and enable linear and sequential signification. These affordances make them effective for applying 
categories (Durand \& Paolella, 2013) and theorizing causal relations (Greenwood, Suddaby \& Hinings, 2002; Suddaby \& Greenwood, 2005), narrating ideas that cannot be "seen", and abstracting from specifics to more general ideas. Verbal texts thus complement the holistic, spatial, emotion-evoking and indeterminate characteristics of visual texts, guiding the assignment of meanings to them (Kress \& van Leeuwen, 2006; Meyer et al., 2018).

However, we know little empirically about how social entrepreneurs can use multimodal discourse encompassing visual images and texts to influence target actors. Can multimodal discourses resolve some of the issues identified in earlier studies of visual images - that is, how to attract attention for an issue, but at the same time, help targets to modify their moral principles regarding an issue and feel capable of taking action on it? Given the important connection of visual images to emotional experiences, we expect emotions to play a significant role when social entrepreneurs use visual images to attempt to mobilize support for a cause. Yet we know little about how the negative emotions in response to a morally shocking image can be transformed into enactment of a cause, particularly when target actors invested in the status quo must both acknowledge their guilt and change their behavior. In this research, we study social entrepreneurs' use of the morally-shocking Midway albatross symbol, focusing on the way they transformed the negative emotions evoked among target actors into positive emotional energy and the enactment of the social entrepreneurs' cause.

\section{METHODS}

\section{Research Context: The Anti-Plastic Pollution Movement and its Symbols}

Plastic pollution, after climate change, is probably the second most important global environmental issue in the $21^{\text {st }}$ century (DG Environment, 2011). Studies estimate that there are at least 5.25 trillion particles of plastics floating in our oceans (Eriksen et al., 2014), causing the death 
of millions of animals as well as health problems in humans (DG Environment, 2011; Van Cauwenberghe \& Janssen, 2014). We report on a nonprofit organization ('the NPO') concerned with plastic pollution that used visual symbols to energize target actors and influence them to enact their cause of "refusing" plastic rather than recycling.

Historically, the US anti-plastic pollution movement involved sporadic beach clean-ups in California from the 1950s to the 1980s (Moore, 2012). It was not until the mid-1990s that the first marine scientists began to actively denounce plastic pollution. In 1994, Captain Charles Moore discovered a vast area of floating plastic debris in the Pacific, which he termed the 'Great Pacific Garbage Patch'. Moore's vivid description of the site attracted media attention and public debate. In response, activists started campaigns and founded associations. They represented the issue through pictures of floating plastic bags, bottles and other debris (Neilson, 2018). Yet, these images were disconnected from daily reality for most people since the Patch was out of sight. Colin, a founder of the NPO described the situation at the time:

"There was a lot of talk about the garbage island, but there was not a photo, and there cannot be, because there is no island of garbage. It is confetti, spread over millions of hectares. If you take a photo of millions of hectares of sea, it is beautiful, it is not a photo that breaks your heart".

In 2009, in an attempt to build momentum along with a coalition of organizations focused on refusing single-use plastics (instead of recycling them, which was the main frame of the industry), five social entrepreneurs founded our focal NPO. The NPO founders shared their passion; all had previous experience on environmental issues and they defined themselves as "social entrepreneurs". Two of them, Sandra and Josephine, were working on a startup aimed at developing a tool to help clean plastic from the ocean. Two others, Colin and Diane, worked in the film industry and met shooting a documentary on the impact of consumerism on the environment. The fifth founder, Leslie, owned a law firm that lobbied for environmental issues in Washington. They all sought to create something bigger - an organization that facilitated tools for change and 
that could serve as an umbrella for other entrepreneurs and smaller organizations. They also sought a new vocabulary and images that could evoke strong emotions. As Colin noted in 2010: "it is a phenomenon that needs strategy...It needs a name, it needs some pictures... We need it to be a movement, which uses a new vocabulary...".

The NPO in 2018 has become one of the largest, most influential organizations in the field of anti-plastic pollution in the USA. Since its founding, it has played a "central role" (interview, Charles Moore, 2010) in coordinating public communication and legislative campaigns. It now is a global alliance of more than 700 organizations in over 60 countries. Aside from the founders (the NPO social entrepreneurs), we studied the actions and responses of NPO staff, such as the social media manager or the innovation manager; NPO advisors, who are prominent people recognized for their knowledge and work on plastic pollution, such as Captain Moore or photographer Chris Jordan; coalition members, which include other anti-plastic organizations that pay membership fees to the NPO to further the anti-plastic cause and coordinate political activities; and volunteers, who participate in NPO activities. We observed how emotion-symbolic work was performed not only by the NPO founders but also by NPO staff and advisors.

While many symbols were used by activists, one image (Figure 1) soon became what The Huffington Post called "the poster child for the 'anti-plastic' movement" (Bassett, 2010). This image was part of a photo series of dead albatross chicks on Midway Island which was taken by Chris Jordan in September, 2009, during an expedition conceived and organized by Colin, one of the NPO co-founders, and Chris. ${ }^{2}$ In 2011, the albatross pictures won the prestigious Prix Pictet Commission prize, the world's leading award in photography and sustainability. Colin and the other NPO social entrepreneurs, staff and advisors extensively used the albatross chick image to

\footnotetext{
${ }^{2}$ Besides the pictures, a documentary was created, which premiered on June 8, 2018, at the United Nations Headquarters as part of the official World Oceans Day Program.
} 
promote target actors' emotional energy and enactment of the NPO cause of refusing plastic in what we term emotion-symbolic work.

$$
==\text { Insert Figure } 1 \text { about here }==
$$

\section{Data Sources and Collection}

To address our research question, we mobilized a rich set of data to study the NPO, the social entrepreneurs and the anti-plastic movement over 8 years, beginning in 2010 when we saw one of the first exhibitions of Chris Jordan's albatross series in Berkeley, California (where we also met Colin), and continuing intermittently until August 2018. Data included semi-structured interviews, naturalistic observations, archival data and online and social media data (Facebook, Twitter, Instagram, media websites and blogs). The aim was to capture, as broadly and representatively as possible, the use of symbols by the NPO. Table 1 summarizes the data and its uses.

$$
==\text { Insert Table } 1 \text { about here }==
$$

Semi-structured interviews. We conducted 50 semi-structured interviews using a snowball sampling approach. Interviews, lasting fifteen minutes to two hours, were recorded and transcribed with interviewees' consent (1,789 minutes transcribed). We conducted 20 interviews with actors that participated in the creation and/or diffusion of the albatross visuals. We started by interviewing Colin, as he was deeply involved both in the production of the visuals on Midway Island and in the symbol diffusion through social media and other means. We also interviewed two more NPO founders and several NPO advisors and staff including social media managers, an innovation manager, and others. Furthermore, we conducted 14 interviews with leaders of the wider plastic pollution movement and 16 interviews with leaders of small anti-plastic organizations and target actors that either have used or been affected by the symbol. We anonymized all informants other than photographer Chris Jordan, whose identity is publicly associated with the images. Interviews 
followed an initial protocol (Patton, 2002), reflecting our research question ("how do social entrepreneurs use visual images and textual interactions to influence their targets to enact a difficult cause?"). We adapted this protocol to the characteristics of the informants and the theoretical constructs that emerged over the course of our research. We used the interviews to understand the NPO and the anti-plastic movement, as well as to develop the key theoretical constructs expressed in this article.

Naturalistic observations. We collected observational data during key events and meetings with the NPO and other anti-plastic pollution organizations. Two of the authors participated in seven NPO events in California from August 2010 to March 2011 and June to September 2013. We organized a workshop, then attended another specialized workshop and a TedX-Talk from which we transcribed 29 testimonials. We had five meetings with NPO founders, members and other local leaders. After 2011, the two authors maintained regular contact with the NPO founders and participated in various events in Europe. These observations provided us with a rich understanding of the context of the anti-plastic movement and the role of the NPO.

Archival data. To increase the internal and external reliability of our analysis and further understand the issue of plastic pollution, we used archival data provided to us by NPO founders, media articles, websites, emails, newsletters, academic articles and two books by key actors (Moore, 2012; Terry, 2012). We also watched five documentaries related to the albatross on Midway Island and on plastic pollution.

Social media and online data. To understand how the NPO social entrepreneurs used the albatross and other symbols, we studied their everyday exchanges on social media. Social media are important spaces for emotional contagion and emotional manipulation in management (e.g. Castelló, Etter \& Nielsen, 2016; Toubiana \& Zietsma, 2017) and other disciplines (e.g. Appel, 
Gerlach \& Crusius 2016; Kramer, Guillory \& Hancock, 2014). Social media enable unobtrusive data gathering (Vesa \& Vaara, 2014), of "naturally situated behaviors" (Kozinets, 2002: 63) and interactions. We collected data from Facebook, Instagram, Twitter, YouTube and newspaper websites to have a representative view of interactions between 2009 and 2018. We periodically reviewed the Facebook pages of the six key U.S. anti-plastic pollution organizations and we systematically downloaded the NPO's Facebook data from October 2009 to December 2010 (when our focal social entrepreneurs managed the account), obtaining NPO managers' permission, and disclosing our presence and affiliation in 2010 on the NPO Facebook page.

We used a software package called Social Data Analytics Tool (SODATO, http://cssl.cbs.dk/software/sodato/) that utilizes Graph API to fetch data and prepare them for analysis (Vatrapu, 2013). Our systematic Facebook data retrieval was complemented by manual verification and the creation of a database in Microsoft Excel. The data consisted of 17,287 lines, including 578 Facebook posts, 2,504 comments on these posts, and 9,983 'likes' (indicating support for a post). We selected the 421 posts featuring "full exchanges"; that is, where the entrepreneur posted on Facebook, the Facebook friends (respondents) replied and the NPO reacted back to the respondents' comments. We first focused on the albatross visuals. We identified 38 full exchanges with a total of 152 comments. On Twitter, we reviewed all 8 hashtags and 4,517 tweets we found relating to the albatross visual, and created a database of those containing full exchanges (628 comments). Using the same strategy on Instagram, we found 23 relevant hashtags and 33 full exchanges, ranging from two to 36 comments each. In addition, we systematically analyzed all 252 comments associated with a YouTube video on the Midway series and 319 comments associated with an article in The Guardian about Midway and plastic pollution, not related to the NPO. We performed this supplementary analysis to distinguish if the albatross visual 
could be so powerful that it alone would be capable of motivating enactment of the cause, without the mediation of social entrepreneurs' multimodal (visual and verbal) emotion-symbolic work in social media interactions. We describe our methods for this supplementary analysis in Annex A.

\section{Data Analysis}

We followed an inductive theory generation approach consisting of three main recursive steps (Gioia, Corley \& Hamilton, 2013).

Step 1: Open coding. We first performed open coding (Strauss \& Corbin, 1990) to identify key actors, the NPO's activities and the interactions between the social entrepreneurs and the target actors. Two researchers sought initial patterns in the data, identifying a set of in vivo codes. Then, all four researchers examined these initial codes to define first-order themes, refining them through intense discussions and "trial-and-error drawings" (Smith, 2002: 395). For example, we first noticed the importance of visuals in the NPO's communications and how images triggered negative emotional expression by target actors, such as "So sad!!!", or "I felt disgusted". Then we observed how entrepreneurs encouraged the enactment of the cause using the albatross symbol. For example, we observed how social entrepreneurs used the symbol to responsibilize target actors for the problem ("you killed those birds"), but also how they made actors feel part of a broader movement capable of addressing the plastic pollution problem (“...we are raising awareness together ... Onward!"). We also noticed that target actors described emotional responses to the symbol which seemed to fuel their enactment of the cause ("Plastics in the ocean killing birds is the last straw for me. REFUSE STRAWS”).

Step 2: Conceptual categories. After our initial open coding, we adopted an abductive approach, iterating between data and theory through axial coding to define theoretical constructs encompassing our empirical themes. For example, considering the strong negative emotions 
triggered by the visual, we turned to the social movement literature and encountered the notion of moral shock (Jasper, 2008; Jasper and Poulsen, 1995). Then we reviewed management research on emotions (Quinn \& Dutton, 2005; Goss, 2008) and the sociology of emotions (Collins, 2004) to understand positive emotions related with the enactment of the cause, and we identified the concept of emotional energy. We refined our initial empirical themes into 10 theoretical constructs involving both work done by the NPO social entrepreneurs to affect emotions and the responses of target actors. Table 2 and 3 shows data examples related to the empirical themes and first level constructs.

$==$ Insert Table 2 and 3 about here $==$

Step 3: Aggregate dimensions and model development. After developing our set of theoretical constructs and identifying the aggregate themes, we sought relationships and causal ordering among these themes by analyzing line by line the conversational vignettes in the Facebook data (Charmaz, 2014). These interactions between NPO social entrepreneurs and target actors followed distinct patterns that were replicated frequently, enabling us to develop an empirically grounded model. We cross-checked our emergent understandings by returning to the interview data to ensure our interpretations were consistent with claims by the social entrepreneurs and other NPO staff and advisors. We also performed 'member checks' (Lincoln \& Guba, 1985), reviewing our findings with NPO social entrepreneurs to ask for specific insights, ensure resonance and address any ethical concerns. Our model of emotion-symbolic work (described in the next section) explains how entrepreneurs used multimodal interactions around a symbol to promote emotional energy in order to evoke the enactment of a new moral standard.

\section{FINDINGS: EMOTION-SYMBOLIC WORK, EMOTIONAL ENERGY AND THE ENACTMENT OF A CAUSE}


Our abductively-generated model illustrates the process by which social entrepreneurs aim to generate emotional energy, converting target actors into identified, energetically-aroused and morally-aligned supporters who enact the NPO's cause. This process is driven by what we call emotion-symbolic work, which we define as the deliberate production and use of symbols, often multimodally, to manage the emotions and emotional energy of target actors in order to influence their actions. Figure 2 depicts the process of emotion-symbolic work which we describe below.

$$
==\text { Insert Figure } 2 \text { about here== }
$$

\section{Emotion-Symbolic Work to Elicit Moral Shock: Symbol Production and Diffusion}

Symbol production. The NPO founders promoted a new approach to the anti-plastic pollution cause: the idea that people should refuse single-use plastics such as water bottles, straws, bags and other disposable plastics. These social entrepreneurs felt that efforts to recycle single-use plastics or clean them up from beaches or the ocean were counterproductive, since they were ineffective at stopping the problem, and they obfuscated the underlying need to stop using plastic. Colin felt that a powerful visual symbol would help to communicate their cause to supporters: "We need an image which breaks our heart" [Colin, 2010].

Colin learned of the Midway tragedy from an oceanographer, and organized a trip to the island, where plastic debris floating in the sea was killing thousands of albatrosses. He also engaged Chris Jordan, a famous photographer interested in the effects of consumerism, to help.

The NPO social entrepreneurs experienced moral shock themselves when they saw thousands of birds that died from ingesting plastic on Midway Island, as two of them describe: “... I just cried my heart out on that beach, "cause she [a bird she was trying to rescue] was the hope... none of them were making it. I just felt... helpless." [Betty, 2018], and "We were in an intimate relationship with animals... $\mathrm{F}^{* * *}$ ! Because I saw it, because I put my hands in the stomachs of the 
albatross, right? Because I have cried and cried and cried on the beaches.” [Colin, 2015].

Those shocks, though painful, also energized Colin.

"I came back from that trip with the batteries loaded.... that lasts until today, it's something that makes a deep impression...you have to honor what you have seen... you make a trip to zone 0 , and then you come back transformed." [Colin, 2016].

Chris and Colin felt the albatross visuals were the perfect symbol materializing the tragedy of plastic pollution, and jointly theorized about the connection between plastic pollution and the Midway albatross symbol through the role of the albatross in native Hawaiian traditions and in the history of Western poetry, finding meaningful coincidences: "of all the birds that could have this tragedy happening to them ... any one of the 700 species of seabirds in Midway ... from all those is the albatross which is mythical and has a long history in poetry" [Chris, 2010]. Theorizing helped the social entrepreneurs to elaborate the chains of cause and effect (Greenwood et al., 2002: 60). Midway, an island of resistance in the Second Word War, served as a rich metaphor for the resistance of plastic: "The metaphor of Midway began to open itself up... I did not realize at the beginning how rich the metaphor was going to be" [Colin, 2010].

One of the most widely diffused visuals of the Albatross series is reproduced in Figure 1. It portrays dead chicks, their stomachs opened to reveal colorful plastic objects - objects we recognize because we use and discard them regularly, revealing our complicity in the deaths of the birds. In contrast to the colorful plastic at the center of the photo, the decaying albatross is a grey outline - a frame. In the film version, the beauty of the setting is shown first: the Pacific Ocean, thousands of flying birds, and adult albatrosses feeding their chicks. The chicks are then shown dying, clearly suffering, and then close-ups of their plastic-filled carcasses are shown. The photos and film convey the idea that albatross parents were feeding their chicks our brightly colored plastic pollution, thinking it was good for them, but the plastic led to the babies' deaths. The images, like those of a crime scene (Wagner-Lawlor, 2016), bear witness, in this case to the horrific 
results of our throw-away culture. In Meyer et al.'s (2018) terms, the images are designed to materialize plastic pollution for viewers, evoking strong sentiments and leading us to connect to the image "affectively, aesthetically and corporeally" (Meyer et al., 2018: 399).

Symbol diffusion. Colin, Chris and other NPO social entrepreneurs, advisors and staff diffused the albatross images at events engaging in multimodal conversations with audiences about the consequences of plastic pollution:

"Seeing his footage and having this dialogue... people in the audience were crying. It was just so powerful... he had these beautiful images from the Atoll of birds flying and he had the gruesome ones..." [Viviana, 2018].

The social entrepreneurs also diffused the symbol on social media: on Facebook (FB), Instagram (INS), Twitter (TW) and blogs. Colin was especially active on FB: "It was very hard work for me.

Some days, I was waking up, sitting in front of the computer and I was there, in my pajamas and without eating until 4 pm. I wanted to be everywhere" [Colin, 2010].

\section{Target Actors' Moral Shock}

Target actors reacted with moral shock to the diffusion of the albatross symbol. Moral shock is a strong emotional reaction to something unexpected that could sometimes lead to the rethinking of moral principles (Jasper, 2011). In our case, moral shock encompassed different emotions, mainly sadness, rage and despair. For example, respondents to the Instagram post below together expressed their utter sadness after seeing the albatross visuals:

INS-12-2017-@ chrisjordan: albatross fledgling on Midway Island, coughing shards of plastic out of its stomach. See the full scene in my film ALBATROSS...

Clementine: So sad

Graveyard lover: "Liking" this just seems wrong, but you've captured something so heartbreaking but important.

Glimpse lady: so utterly sad.

Arrested development: This totally broke my heart last night...

In the next sections, we present further examples in which the diffusion of the symbol by the social entrepreneurs prompted moral shock in target actors. The entrepreneurs then used emotion- 
symbolic work to attempt to embed target actors in the social movement, fostering the transformation of actors' emotions into emotional energy.

Emotion-Symbolic Work to Foster Emotional Transformation: Embedding Target Actors into the Movement using the Symbol

After producing and diffusing a symbol, NPO social entrepreneurs used three emotionsymbolic work activities to embed target actors into the social movement: connecting to the cause, connecting to the collective identity, and connecting to the NPO and its social entrepreneurs.

Connecting to the cause. To connect target actors to the NPO's cause, social entrepreneurs used anchoring and responsibilization. In multimodal semiotics, anchoring between verbal and visual modes refers to a process where "verbal captions can narrow down the content of images and make it more specific" (van Leeuwen, 2005: 77, building on Barthes, 1977). Similarly, we argue that anchoring in emotion-symbolic work operates by using a symbol (and the moral shock it evokes) and verbal interactions to educate target actors about the NPO's cause: the need to refuse disposable plastic, as shown in this interaction:

FB-08-2010-NPO: Midway Journey albatross photos by Chris Jordan inspire children to take action against plastic pollution.

Rick: It's gross Really opens your eyes I am trying 2 live without plastic \& am into the Environment so don't throw my rubbish about or abandon it willy nilly. Ppl need 2 think \& dispose of their trash in a responsible manner.

NPO: Thank you Rick for your passion and support... Plastic pollution is not the result of improper disposal .... It is a problem of design: plastic is toxic and lasts hundreds of years ... The message that albatrosses are bringing us is that there is no away and that we need to radically change our ways ... to refuse single use plastics.

The NPO used verbal interactions to try to reshape the respondent's rage against those who abandon their rubbish "willy nilly", anchoring the message of the symbol to the NPO's cause, both by clarifying the problem ("plastic pollution ... is a problem of design") and by providing solutions ("we need to radically change our ways ... to refuse single use plastics").

To connect them to the cause, the NPO also responsibilized target actors, that is, stressed 
their own responsibility for the birds' deaths and the problem of plastic pollution due to their use of disposable plastic. ${ }^{3}$ In doing so, the NPO social entrepreneurs sometimes used anthropomorphic metaphors like parenthood to connect the albatross image to target actors - they could imagine the way they "stuffed" their own children with plastic. In this way, responsibilizing elicited both targets' ownership of the plastic pollution issue and guilt about their part in it.

FB-07-2010-NPO: "Did you watch the video of the baby albatross stuffed with plastic? How about humans stuffed with plastics? That's us. Babies are born prepolluted with plastic additives. These are in amniotic liquid, breast milk and umbilical cord blood... STOP using single use plastics (the main culprits of plastic pollution) and don't let plastics touch your food and drink.

In the next example, target actors expressed acute sadness after seeing the Midway video.

Billie called for recycling. Rather than accepting Billie's statement, the NPO social entrepreneur reinforced the NPO's cause, responsibilizing Billie and other target actors:

FB-07-2010-NPO: Midway Journey returns to the island!... Please fan Midway Journey Ignatius: I didn't think my heart could break anymore, but it can, and does.

Jack: I couldn't watch the whole thing. It made me sick to my stomach. Rethink plastic! Jill: A horrific irony, watching the animal decomposing around the non-biodegradable plastics... Billie: This is so sad. People should take recycling seriously NPO: Billie, 'recycling' is not the solution. Plastic pollution is not a problem created by bad people who don't 'recycle'. You killed those birds, I kiled [sic] those birds, we all did.

Thus, the NPO social entrepreneur linked the moral shock elicited by the symbol to the actor's own responsibility for the problem ("You killed those birds..."). However, rather than leaving Billie alone, he shared the responsibility (“...I kiled [sic] those birds, we all did”), to connect Billie to the collective identity of the anti-plastic movement using the symbol, as we describe next.

Connecting to a collective identity. Connecting target actors to the emerging collective identity of the anti-plastic broader movement involved promoting solidarity and promoting hope in the efficacy of collective action. Promoting solidarity offered relief to target actors from the

\footnotetext{
3 Responsibilization refers to a "process whereby subjects are rendered individually responsible for a task which previously would have been the duty of another... or would not have been recognized as a responsibility at all" (Wakefield \& Fleming, 2009: 277).
} 
moral shock evoked by the symbol and the guilt associated with being responsibilized for the problem, and thus it helped to transform negative emotions into positive ones. As illustrated in the next interaction, the moral shock evoked by the symbol sometimes included strong expressions of despair, suggesting that self-efficacy was undermined.

FB-06-2010-NPO: This video tells the whole story. The story of plastic pollution, and also the story of why we do what we do Monique: I just can't stand it anymore, I have refused plastic for years... The simple sight of it disgusts me. To see these beautiful animals suffering so much at the expense of human greed and consumption.

Forrest: I'm completely devastated. Watching that bird ingest a plastic bag is unbearable. Fantastic video.

NPO: To those feeling overwhelmed: first, let's remember that we are not fighting all plastic in the world. 'Only' single use plastics, and those that leach toxic chemicals into our food and drink. Those bad uses of plastics are the ones we care about.

Sadness in this interaction was so profound that even veterans felt "overwhelmed". ("I just can't stand it anymore", "I'm completely devastated"). Then, the NPO anchored that reaction with "bad uses of plastics", and attempted to create solidarity, using first person plural pronouns to connect target actors to the cause. Feelings of we-ness, according to Polletta and Jasper (2001: 290), are at the core of the "emotional satisfactions" of collective identity. Target actors were included in the emergent collective identity which "cares" about the albatross and plastic pollution.

Connecting to the collective identity was also used to attenuate the burden of responsibility:

FB-11-2012-NPO: What is happening to these birds is very metaphoric. Stuffing themselves with colorful things that have no value and that are killing them? Feeding those to their chicks? But we are raising awareness together. Thank you so much for coming along on this journey. Onward!

The horror of being responsible for massive pollution and poisoning was tempered by "raising awareness together". The term "Onward", which means to continue forward in a direction, was used repeatedly in interactions with target actors around the symbol.

"It is difficult ... you have to have a special kind of inner processes for not getting mad... That is the reason of all this rhetoric of onwards, we are together, we are learning together... I wanted to highlight also that we are pioneers, we are the vanguard of a movement" [Colin, 2015].

In Colin's words, the "rhetoric of onwards" was intentionally used to promote hope in the 
efficacy of collective action, as target actors were induced to believe that they were partly responsible for the problem but that they were also part of an emergent collective identity constituting "the vanguard" of the anti-plastic movement.

"You refuse because you remember the albatross... emotion is your energy, but also if you connect directly to $400,000 \ldots$ you can get fried... we helped each other to process these emotions and express them... through the call to action." [Colin, 2010]

As the NPO social entrepreneur argued, connecting actors to the collective identity by promoting solidarity and hope in collective action offered actors relief from the horrors and responsibilities of the plastic problem, symbolized by the albatross visual.

Connecting to the social entrepreneurs. In addition to connecting to the cause and the collective identity, the social entrepreneurs also worked to connect target actors to the NPO, using the symbol to establish the NPO's legitimacy and the social entrepreneurs' influence as the expert leaders of the anti-plastic movement. The NPO social entrepreneurs needed legitimacy and influence to be able to convince target actors to refuse single use plastics, and not participate in beach clean ups or recycling. Legitimacy and influence were also at the core of the NPO business model, as their extensive impact in social media was used by fee-paying members, like other antiplastic non-profits and companies, to promote their campaigns and products. The albatross symbol helped the social entrepreneurs to establish the NPO's legitimacy and position it as a central organization in the broader anti-plastic movement, as explained by Alex, an NPO advisor:

"I think [the symbol] has quite an enormous role in this... it wasn't until he took those pictures of those chicks... with their stomachs filled with plastic that - I mean like that picture is worth a thousand words and those images really shocked people, woke people up, and got a lot of people concerned. I feel like... the [NPO] ... they sort of focus... systematically at the issue." (Alex, 2013).

The leading role of the NPO allowed social entrepreneurs to discipline target actors, as we saw in the responses to Billie and Rick (and in many other interactions), chastising them for supporting recycling. The social entrepreneur needed influence, since formal authority is rarely available in 
interactions with potential social movement supporters. As the next interaction shows, the symbol helped to establish social entrepreneurs' influence as expert leaders of the movement:

FB-04-2010-Marc: It's not the solution but it's a start... Water in box not in plastic! This product is $100 \%$ recyclable and $97 \%$ compostable. Check it out...

NPO: REFUSED. No thanks...this is nothing but 'a less plastic bottle'. Lined with polyethylene and with top, seal and cap made with polypropylene. I've retrieved these caps from inside carcasses of baby albatrosses with my own hands.

In the interaction, the social entrepreneur used his own proximity to the symbol of the albatross to discipline Marc, positioning himself at the center of the group that not only knew how to solve the plastic pollution problem, but had also directly witnessed the plight of the albatross. The social entrepreneurs thus connected target actors to themselves and the NPO with the symbol. Summarizing, although we analyzed the three emotion-symbolic work connecting activities separately, the three worked together to embed target actors into the movement. The symbol, and the emotions it evoked, played a key role in connecting target actors to the cause, the collective identity and the social entrepreneurs and NPO, each one adding to the depth of the connection. These emotion-symbolic work activities were used in complementary ways to embed target actors and encourage them to enact the cause, as shown in the response below to a suggestion by Maryann that the oceans should be cleaned.

FB-03-2010-NPO: Dear Maryann,... The 'floating island of plastic' does not exist(!) The typical piece of plastic in the ocean is tiny, barely visible... This makes cleaning the oceans not feasible, technically or economically... [NPO] believes in stopping plastic pollution at the source. This is something we can do now. Please help us by learning more about what this problem really is, about the solutions that we can implement now, and please help us spread the word as well. Here's some reading that might be helpful: http://.../ And a video to watch -where you can put a face to the person writing these lines- http://... It was filmed on Midway Atoll, near the heart of the so called Pacific garbage patch. Thank you so much Maryann! We are together in this. Onward!

Just as with other examples we noted, the social entrepreneur here 'disciplined' the target actor by educating her that ocean cleanups were not a viable solution, but then used emotionsymbolic work to soften the blow. The social entrepreneur connected the target actor to the cause, anchoring the interaction to the problem ("The 'floating island of plastic' does not exist(!)..."), and 
the NPO's solution ("stopping plastic pollution at the source"). Then, he connected to the collective identity by promoting hope in the efficacy of collective action ("This is something we can do now... We are together in this. Onward"), and positioned the NPO as the leading voice in the issue of plastic pollution (“[NPO] believes in ...”), presenting the NPO's expertise ("here's some reading") and using the social entrepreneur's proximity to the albatross symbol ("It was filmed on Midway Atoll") to reinforce his influence. The embedding work of the NPO succeeded, as suggested by Maryann's subsequent activity on Facebook (9 new Facebook posts) during the year. In her next Facebook post, Maryann pledged to act on recycling policies: "Has anyone notified them yet of their own stupidity? I think I'll write a letter right now. Maybe we all should" (FB-04-2010). In the following section, we show how emotion-symbolic work transformed the negative emotions of target actors like Maryann into emotional energy to enact "refuse".

\section{Target Actors' Emotional Energy}

The transformation of the moral shock elicited by the symbol into enduring emotional energy was the ultimate goal of the NPO social entrepreneurs' emotion-symbolic work. As Chris argued, his main challenge in the Albatross film (www.albatrossthefilm.com) was to overcome moral shock with positive emotions which could "allow ourselves to feel deeply enough that it transforms us and our future... Once you feel love, you can be more courageous and make more radical choices." [Chris, The Guardian, 2018]. We found three elements of emotional energy in response to the emotion-symbolic work: energetic arousal, identification and moral emotions.

Energetic arousal. Energetic arousal is the "feeling that one is eager to act and capable of acting" (Quinn \& Dutton, 2005: 36), consisting of individual motivation and collective excitement. Target actors expressed energetic arousal after being exposed to emotion-symbolic work. In the following interaction, an NPO blog featured the albatross visual and responsibilized target actors:

Blog-09-2015-NPO: The photograph has been widely circulated for years: a mess of feathers and 
bone, beak and bottle caps. For many, it's a shocking introduction to the problem of plastic pollution. As the image pops in our newsfeeds and the sum of its elements comes together in our minds, a single thought hits hardest — we did this.

A target actor testified how the NPO blog made her feel shame and "heartbreaking" sadness:

Blog-09-2015-Julie: "Powerful image. It was heartbreaking to learn... that both my activities and my generation's consumer path has led to horrific suffering... Shame and sadness were my first feelings but they change nothing. I AM MOTIVATED! And I am grateful for the armies of people who will not sit down".

Julie's emotions, which alone "change nothing", were transformed into motivation to refuse plastic by the social entrepreneur's emotion-symbolic work. The capital letters in the response indicate individual motivation as part of the respondent's energetic arousal after the transformation of the initial sadness evoked by the symbol. One social entrepreneur described how, through multimodal emotion-symbolic work, target actors' emotional shock was indeed transformed into energetic arousal in the form of motivation to act: "They draw horrified responses lots of times... it really speaks to people... this picture says a thousand words... it just helps start the dialogue... their emotions build and they wanna do something, they wanna act" [Sabrina, 2018].

Collective excitement was also experienced in the transformation of shock into energetic arousal. Helena, a NPO staff member, explained the emotional transformation process that began with the symbol and ended in getting excited to act: "It's a ladder of engagement... from that first step of seeing the symbol... and then going all the way to that step of getting activated and getting excited about stopping plastic pollution in the community" [Helena, 2018]. The "community" is an essential part of being "activated" and "excited" by energetic arousal. Identification with the collective is the next element of emotional energy.

Identification. The emotional energy generated through emotion-symbolic work also involved identification with the NPO and its cause. In the following example, a target actor pointed to the symbol as the source of her collective identification. 
FB-11-2009-Liz: My son and I and now daughter have used metal bottles for at least a year - that's a first step. Now onto more plastic elimination...

NPO: Right on, Liz. Onward!

Liz: I was so sad to hear that the mother albatross feed the plastic to their babies and they die of mal-nourishment. We really have to stop this...

Liz expressed identification with the anti-plastic movement when saying "We really have to stop this" after the NPO promoted solidarity to connect her to the collective identity ("Right on, Liz. Onward!"). In a second example, after the social entrepreneur fosters identification with the organization, Laura and Maria expressed organizational attachment:

FB-01-2011-NPO: Hey Facebook fans and friends we need your help. Can you tell us in your own words why the NPO is an important organization to you?...

Laura: Oh, I can answer that: NPO is awesome. For me, it is the strength behind my message...The loud voice behind my small one...

Maria: I think of you guys EVERY day - in the kitchen, at the takeout, at the office....My son is sick of me grabbing a plastic bag out of his hand and saying 'Don't kill birds!'

Maria identified directly with the NPO ("I think of you guys EVERY day"), and pointed to the albatross symbol as the source of the emotional energy needed to discipline her son to the cause. Laura also clearly showed attachment to the NPO.

Moral Emotions. Finally, emotional energy includes moral emotions, or feelings associated with doing the right (or wrong) thing (Haidt, 2003). These emotions are reflected in target actors showing they are internalizing the cause of plastic pollution in their choices and feeling indignation. In the next exchange, after the NPO social entrepreneur shared the symbol and engaged with them in emotion-symbolic work, Mina and Kora showed they internalized the cause, crediting the information acquired in NPO exchanges with affecting her choices to fit the cause.

FB-07-2010-NPO: Unbelievable footage just uploaded by Midway Journey... Soon more and more of us will be choosing to REFUSE single use plastics

Mina: From now on I will TRY not to buy plastic stuff. It will be hard...but I will try. I already recycle, but that isn't good enough.

Kora: Mina, I am with you. Thanks to this information, we are empowered to make conscious choices and appropriately thoughtful changes.

After NPO emotion-symbolic work, connecting the visual to the "refuse" cause, Mina realized 
that her previous behavior (recycling) was not morally "good enough". Kora was "empowered" by the symbol to make "appropriately thoughtful changes". In another example, Helena internalized the cause and related this process to the symbol: "you can't... use a plastic bottle of water or soda without thinking of that photo... it has an impact on our daily life and the choices we make" [Helena, 2018]. Similarly, a NPO staff member described target actors' reactions to emotion-symbolic work in a campaign focused on refusing specific plastic products (such as plastic bottle caps or straws). The campaign used the symbol to point to those products appearing in the dead carcasses of the albatross portrayed in the visuals: "Once they have that shock moment that they realize it is a material that they've thrown away they then start to look at their own lives... it's almost like holding up a mirror to their own lives." [Janette, 2018]. The moral "mirror to their own lives" created by the social entrepreneurs' emotion-symbolic work helped target actors to internalize the cause after the "shock moment", focusing on refusing concrete objects.

Moral emotions were also expressed when target actors showed feelings of indignation. In the previous interaction, after Kora's comment the NPO once more anchored the meaning of the albatross visual to "refuse". Then Angeline, a target actor, advocated refusing straws:

FB-07-2010-NPO: REFUSE using single use plastics. Those are the main contributors to plastic pollution ... Onward!

FB-07-2010-Angeline: A woman walks into a bar. The bartender says, 'What can I get you?' The woman says, 'I'd like a glass of room temperature water. No ice. and do NOT give me a straw.' It's no joke. Plastics in the ocean killing birds is the last straw for me. REFUSE STRAWS. Give lip service to your glass. Life SUCKS too much.

Angeline's indignation (“It's no joke ... Life SUCKS too much”) about single use plastics is beyond the moral shock associated with the symbol. Instead, her proud refusal of plastic straws indicates that after emotion-symbolic work, she feels moral emotions associated with the 'right' way of living, without plastic, through her daily efforts ("Plastics in the ocean killing birds is the last straw for me"). 
In sum, emotional energy builds up in interactions and becomes infused in symbols, persisting over time (Collins, 2004). Together, energetic arousal, identification and moral emotions comprised the emotional energy that actors experienced as a result of the emotionsymbolic work of the NPO social entrepreneurs. We observed that the emotional energy associated with the symbol fueled enactment of the cause.

\section{Target Actors' Enactment of the Cause}

All emotion-symbolic work activities aimed to manage the emotions and emotional energy of target actors in order to encourage the enactment of a cause. In our study, we identified three forms of enactment: pledging to act, performing the cause, and evangelizing.

Pledging to act. NPO staff indicated how people reacted, expressing their intention to act after being exposed to the NPO's emotion-symbolic work.

"(When looking at the pictures) I find a lot of people, they almost feel like a sense of blame and turn the whole problem into something which will empower people and make them want to change their lifestyle" [Janette, 2018].

The initial emotional shock thus was "turned" into "something" (emotional energy) to invigorate activists to pledge to act. Similarly, in earlier quotes, target actors such as Kora, Mina, Helena and Angeline all related their shock to how they would enact the cause.

Performing the cause. People not only pledged to act but also performed the cause of refusing plastic in response to the NPO's emotion-symbolic work.

FB-11-2009-Liz: I was so sad to hear that the mother birds feed the plastic to their babies Went shopping this weekend... and our first bag was PAPER and it was COOL! so we just used it to put everything else in and declined on the plastic. Little by little...

After learning about refusing plastic from the NPO social entrepreneurs, the target actor changed her behavior "little by little". Similarly, Laura, acknowledged performing the cause after watching the Midway video and being connected to the cause by social entrepreneurs:

FB-07-2010-Laura: So hard to watch but it definitely causes me to change my behavior and reduce 
plastic consumption...

Barbara also shared her experience of performing the cause after being exposed to the albatross visuals during an event organized by the NPO:

“...It was a dead albatross chick carcass filled with plastic pieces... all of a sudden the connection was made. I was harming a creature that I didn't even know previously existed and I had to stop just like that. So I ask myself what would it be like to try to live without plastic - is it possible could I actually do it?... This is all the plastic waste I've generated since January of this year. The average American - about a hundred pounds of plastic waste per year. This is under two pounds..." [Barbara, 2010].

Evangelizing. In some cases, target actors' enactment consisted not only of pledging to act and performing the NPO's cause, but also of evangelizing to others by diffusing the albatross symbol. For example, this tweet shows the diffusion of the symbol. It was retweeted 27,906 times and received 447 comments.

TW-01-2018-@Dickensianguy: Because they cannot be seen too often...here - again - are Chris Jordan's canonical images of albatross chicks on Midway Island, their bodies rotted down around the plastic that killed.

In another example, Carsten described his diffusion activities: after being exposed to the symbol, he "was absolutely disgusted" and "felt helpless". Once he started to diffuse the symbol, his initial moral shock was transformed into long-term emotions fueling evangelizing:

"That feeling you get when you actually pass on something and it creates change, I think is addictive... This is something I've been really passionate about for a long time...it ignites a fire and all it does is keep building and it makes them more inclined to spread the message and tell people about it, which is really cool" [Carsten, 2018].

Enactment thus was not limited to just changing one's own behavior, but also included "addictively" spreading the symbol to others to "create change". Like an evangelist, Carsten made sure the albatross visuals "ignited the fire" of emotional energy in others. In this way, the evangelizing enactment of target actors restarted the emotion-symbolic work cycle, as shown in the dotted arrow in our model.

Could the albatross visual be so powerful that it alone would be capable of motivating 
enactment, without the social entrepreneurs' multimodal (visual and verbal) emotion-symbolic work? To answer this question, through supplementary data, we examined the use of the albatross visuals in other media, which did not involve emotion-symbolic work. Specifically, we analyzed over 500 comments associated with a Guardian article and a YouTube video, both diffusing the albatross visuals but not connecting the symbol to any concrete cause, as the intention was just to expose the Midway tragedy. Our analysis (presented in detail in Appendix A) showed that while the visuals evoked moral shock, they usually did not turn the emotions into any sense of personal responsibility for the problem. Furthermore, the long-term involvement with the problem that comes from identification with a broader movement or specific organization also was largely absent from these comments. We conclude that without the emotion-symbolic work undertaken by social entrepreneurs, even very powerful visuals are unlikely to feature the emotional transformation process that would motivate enactment of a difficult cause. The visual is important but not sufficient, emphasizing the need for multimodal emotion-symbolic work.

\section{DISCUSSION}

In this article, we introduce the concept "emotion-symbolic work" which involves the deliberate use of symbols in multimodal interactions to manage the emotions and emotional energy of target actors to evoke the enactment of a cause. Our findings have significant implications for social entrepreneurship and for the emerging literature on the use of visuals in organizational research, showing that multimodal interactions can transform negative emotions evoked by visuals into positive energy and enactment. We argue that our findings also have implications for the broader field of management, as emotion-symbolic work can be used in many change contexts.

\section{Influencing Others to Enact Change}

Influencing others to change is a broad strategic problem that applies to multiple domains. 
Using symbols to affect people's responses to issues has proven important for influencing change. Hambrick and Lovelace (2018), for example, described how executives used symbols to induce firm members to support a new strategic theme. Zilber (2011) studied how Israeli tech industry participants combined symbols and discourses at industry conferences to affect power relations, identities and meanings. Ruebottom and Auster (2018) showed how a social movement used experiences and symbols to create emotional energy and convince youth that they could and should engage in social change, while Massa et al. (2017) showed how cool climate wineries created rituals and symbols to turn customers into evangelists. What all these examples have in common is that in each case, people influenced social-symbolic structures to effect desired outcomes, usually by affecting the emotions of target actors.

Lawrence and Phillips (2019) reviewed various forms of work intended to influence socialsymbolic structures, such as institutional work (Lawrence \& Suddaby, 2006), cultural work (Lounsbury \& Glynn, 2001), and emotion work, involving conscious efforts to affect feelings (Hochschild, 1979; Rafaeli \& Sutton, 1987). Emotion work has been investigated at the individual level within organizations (Rafaeli \& Sutton, 1987), at the field level (Gill \& Burrow, 2018; Massa et al., 2017), in community and cross-field interactions (Cartel, Boxenbaum \& Aggeri, 2019; Fan \& Zietsma, 2017; Farny, Kibler \& Down, forthcoming) and even at the national level (Moisander, Hirsto \& Fahy, 2016: 969). Emotion-symbolic work fits within this broad set of strategies of using symbolic meanings to attempt to convince others to change. Yet, until recently, little work has connected the use of visual symbols to affect emotions in service of institutional change projects (see Jarvis et al., forthcoming, and Meyer et al., 2018, for exceptions).

Our work contributes to this theme. We identified several interrelated emotion-symbolic work activities performed by social entrepreneurs, including the production and diffusion of a visual 
symbol, followed by multimodal interactions to make the symbol meaningful and use it to embed actors into social structures. In our case, social entrepreneurs worked to triple-embed target actors: connecting them to a cause, a collective identity and an organization in order to facilitate their emotional transformation and ongoing enactment of the cause. Farny, et al. (forthcoming) highlighted the importance of close personal interactions for the development of collective emotions, which were constituted by and constitutive of institutional work in social entrepreneurship in Haiti. Our findings extend their work by showing how emotion-symbolic work online was powerful enough to have similar effects on collective emotions and collective enactment, despite the usual fragility of online relationships.

Emotion-symbolic work was effective in our case even when social entrepreneurs had to discipline target actors to ensure the faithful enactment of the cause. Overt discipline is difficult in social movements (Tarrow, 2010), voluntary organizations (Bunderson \& Thompson, 2009) and other organizations where organizational members tend to reject formal hierarchies (Hatten, 1982), because of its potential alienating effects on supporters. Yet, by presenting themselves as knowledgeable and legitimate, and by connecting themselves so directly to the symbol, the social entrepreneurs built a position of power (Lawrence \& Buchanan, 2017). This position enabled them to normalize and naturalize certain values and practices through overt discipline and emotional transformation, which gradually led to people disciplining themselves to enact a cause.

Emotion-symbolic work thus represents a very powerful tool for social influence, which can be used by social entrepreneurs and other influencers to encourage their targets to energetically enact their cause. Yet, it also suggests several avenues for further research. How can social entrepreneurs maintain control over these social influence processes? How can they direct the energy they evoke over time? How does competition evolve between different social entrepreneurs 
working on similar causes? How sustainable can emotion-symbolic work be? How does the effect of emotion-symbolic work differ across issues and contexts, such as in strategic change processes in business, public service campaigns by government or social movements? And, what are the potential dark sides of emotion-symbolic work?

\section{Emotions in Social Entrepreneurship}

Researchers have identified the importance of entrepreneurs' own compassion and empathy as a key motivating factor for social entrepreneurship (Bacq \& Alt, 2018; Grimes et al., 2013; Miller et al., 2012; Shepherd \& Williams, 2014) and others argue that passionate leadership is required (Thorgren \& Omorede, 2018). Surprisingly, however, evoking others' emotions has not been a significant focus in the social entrepreneurship literature. Work that focuses on commercial, cultural and institutional entrepreneurship has provided some insights. For example, Jennings et al. (2015) found that dramatic performances and visual objects used together by yacht designers facilitated emotional arousal in contributing actors, improving the context for innovation. Elias et al., (2018) took a relational perspective to study the emotional, embodied cocreation process of aesthetic value among art entrepreneurs and their clients. Some studies of consumer evangelists (Jones \& Massa, 2013; Massa, et al., 2017), social movements (Goodwin et al., 2001; Jasper, 2011; Ruebottom \& Auster, 2018), and religious proselytizers (Tracey, 2016) have shown how emotions affect passionate action and the commitment of followers. Gray, Purdy and Ansari (2015) argue that emotions are amplifiers of frames for institutional change.

Our study extends this work and draws attention to the potential of emotional resonance (Giorgi, 2017) in social entrepreneurship and other change projects, reinforcing the actiongenerating potential of compassion (Grimes et al., 2013; Rynes, Bartunek, Dutton \& Margolis, 2013) and moral outrage (Goodwin et al., 2001; Rao, 2008) not just for entrepreneurs, but also for 
their potential supporters. We argue that affecting emotions is particularly important when people must be persuaded that their own behavior is "wrong" and that it must be changed in ways that are often uncomfortable and deviant relative to their social programming.

While most studies of social entrepreneurship focus on positive emotions, we observed more negative or mixed emotions, including combinations of rage and compassion, guilt, sadness and despair. The rage and compassion combination signals that audiences felt themselves to be in relationship with the birds in the photos, connected in a way that facts and rational arguments rarely provide. The responsibilization work that social entrepreneurs did to activate guilt cemented that connection, anchored in the cause. Guilt is a difficult emotion to work with, however, when trying to attract potential supporters. Delmestri and Goodrick (2016: 239) found that people tended to look away, engaging in denial of ethical dilemmas regarding the consumption of animal products rather than acknowledging "an implicit moral reproach". Jarvis et al. (forthcoming) found that animal rights activists suppressed their emotions to avoid being seen as too fanatical by potential supporters who resisted activists' guilt-inducing messages about their food choices. Tracey (2016) found that instilling guilt was an important part of the conversion processes of Alpha Christians, but that it also alienated some people who felt manipulated. Climate change denial may in part also be an attempt to avoid guilt (Hoffman, 2011). Yet, our study suggests that personal responsibility for a problem may be necessary to evoke enactment. Because target actors, in our case, were actively stimulated to be in relationship with the albatross by the characteristics of the visual symbol, they were more likely to acknowledge their own complicity. When does guilt have a motivating role and when does it alienate? In our data, the emotion-symbolic work of the social entrepreneurs helped to offer relief from the targets' grief and guilt through the hope associated with collectively enacting the cause and through solidarity. 
Further research is required to tease out the effects of different emotions, both individually and in combination. Relevant questions include: How do different emotions work differently towards enactment? What combinations of emotions increase emotional energy? How are different actors affected by different emotions?

\section{Visual Images and Multimodality}

Visual images affect our emotions (Joffe, 2008) and make us more reflexive about ourselves and our world. They signify meaning more holistically and communicate sensory experience better than verbal text, show complex relationships at a glance, and can situate the viewer in relationship with the image (Meyer et al., 2018), reframing issues and establishing expertise (Christensen, 2018). In our study, the powerful image put viewers in intimate relation with albatross chicks and highlighted that the viewers' everyday plastic detritus was responsible for killing these chicks.

Through seeing even familiar things in a different way, we develop a new way of seeing and being in the world. Yet, as other studies have identified (Mattoni \& Teune, 2014), presenting evocative images alone is insufficient to ensure that target actors will become active supporters of a cause (see also Appendix A). Evocative humanitarian photos may attract immediate attention (Dencik \& Allan, 2017), but their power goes down over time as donor fatigue sets in and the image becomes normalized (Fehrenbach \& Rodogno, 2015). Studies of climate change visuals find that such images may attract attention, but may also depress people's efficacy, paralyzing them into inaction (O’Neill \& Nicholson-Cole, 2009). Indeed, our interview and social media data showed despair and feelings of being overwhelmed when people responded directly to the image. Translating compassion into action requires a belief that one can act effectively in a socially valuable way (Bacq \& Alt, 2018). The multimodal emotional transformation process we identified overcomes the efficacy problem by convincing target actors that they can act effectively, in 
solidarity with others, resolving the tensions identified in prior work on negative emotions and visual images (Chapman, Corner, Webster \& Markowitz, 2016; O’Neill \& Smith, 2014).

While prior research in entrepreneurship has focused most often on the use of narratives, text or frames (e.g., Giorgi, 2017; Khaire \& Wadhwani, 2010; Navis \& Glynn, 2010; Weber, Heinze \& de Soucey, 2008; Wry, Lounsbury \& Glynn, 2001) to affect audiences, and has also included the effects of décor and dress (Clarke, 2011; Zott \& Huy, 2007), very little work in management has focused on visuals (Christensen, 2018; Lefsrud et al., 2015; Meyer et al., 2013, 2018), particularly in the social entrepreneurship literature. This general lack of attention to visual images is remarkable since visuals are everywhere in our world and they have the power to move us, as advertisers and social entrepreneurs alike are well aware (Joffe, 2008). A notable exception is recent work by Jarvis et al. (forthcoming), which showed how animal rights activists used images and video to evoke emotions among potential supporters yet suppressed their own emotions to avoid alienating target actors. Instead, they waited for targets to have their own emotional epiphanies. Rather than this slow process, our study shows how social entrepreneurs can also evoke and manage emotions more directly through emotion-symbolic work.

While there are multiple branches of organizational research that focus on influencing people to change their behavior, including strategic change (Hambrick \& Lovelace, 2018), sensegiving in organizational change (Gioia, Thomas, Clark \& Chittipedi, 1994), institutional change (Suddaby $\&$ Greenwood, 2005), change driven by social movements and social entrepreneurs (Farny et al., forthcoming; Hiatt et al., 2009), and legitimation of new product categories (Massa et al., 2017), the paucity of research on multimodal influence processes suggests we are attending to only a fraction of the means by which humans influence one another. Compounding this problem, not enough research has emphasized the strategic manipulation of emotions in studies of change, for 
which symbols, including visuals, may play a significant part. Our findings illustrate how multimodal interactions including visuals can be a powerful tool in the arsenal of social entrepreneurs and other leaders, deserving of much more research. Are particular types of visuals more powerful than others? Does the impact of visuals depend on audiences' epistemologies and cultural codes? Under what conditions are visuals more persuasive than other cultural elements? Is their impact more or less durable or agency-provoking than that of other cultural elements? How do visuals work together with other cultural elements in multimodal communications? While we only begin to address these questions, we join others (Meyer et al., 2018) in calling attention to this important, and mostly missing aspect of research in management.

\section{Limitations and Boundary Conditions}

Social media data feature brief exchanges, without the benefit of nonverbal cues, and thus could be thought to be a relatively weak platform for emotion. Yet the use of images, emoticons, internet slang such as LOL and memes augment the ability to convey emotion on social media. In addition, such public and naturalistic digital data have significant advantages since they provide digital traces of reactions and interactions in-the-moment. Prior studies have shown that social media can be replete with emotions (Castelló et al., 2016; Mattoni \& Teune, 2014; Toubiana \& Zietsma, 2017). Furthermore, we used multiple sources of data in the study, including interviews, archives and observational data, to ameliorate this limitation.

Our study focused on emotional identification with and enactment of a challenging cause challenging because it required acknowledging one's own guilt and taking actions that are difficult in a world where plastic is ubiquitous. This is a boundary condition of our study. When causes are challenging, we believe emotions are critical mechanisms affecting enactment and visual images may be important for disrupting taken-for-granted beliefs. With easier or more attractive causes, 
emotion-evoking symbols like the albatross may be less necessary, and rational argumentation may be enough to spur people to action. However, even with less difficult causes, emotionsymbolic work is likely to energize people to identify with and enact a cause more quickly, more intensely and more durably than would rational argumentation, depending on institutional norms around emotion display rules (Hochschild, 1979; Voronov \& Weber, 2016). Further research is needed that takes seriously the influence of emotions on persuasion (Jarvis et al., forthcoming; Tracey, 2016), resonance (Giorgi, 2017) and identification (Polletta \& Jasper, 2001).

\section{Implications for Practice}

Despite limitations and boundary conditions, our findings have much broader implications than the specific social entrepreneurship context we studied. Although our social entrepreneurs were skilled individuals who worked hard on social media diffusion and who had an intimate relationship with the symbol, we believe the model of emotion-symbolic work we induced provides a recipe that could be replicated by others and is potentially widely generalizable. At the most abstract level, our study sheds light on how leaders of any sort can inspire and energize others to enact their cause, even when doing so is difficult. Executives and managers of organizational change projects can use emotion-symbolic work to energize employees, extending work on symbolic influence (Hambrick \& Lovelace, 2018; Zamparini \& Lurati, 2012; Zott \& Huy, 2007), social issue selling (Sonenshein, 2006; Wickert \& de Bakker, 2018), and sensegiving (Gioia et al., 1994; Kaplan, 2008; Maitlis \& Lawrence, 2007). Political leaders (Allison, 1971) and leaders of religious (Tracey, 2016) and social movement organizations (Eyerman, 2005) can use emotionsymbolic work to energize potential supporters and convert them to their cause. Entrepreneurs of all sorts can use emotion-symbolic work to energize and engage customers, funders and others to support their businesses (Jennings et al., 2015; Massa et al., 2017; Ruebottom \& Auster, 2018). 
Cross-sector partnerships can use emotion-symbolic work to build shared moral principles and collective identity among members, energizing the enactment of a shared agenda (Fan \& Zietsma, 2017). While other studies have provided insights into how emotions influence collective identification and enactment (Farny et al., forthcoming), our study provides a more detailed examination of the emotion-symbolic work that leaders and entrepreneurs can do to build support for their causes, beginning with attracting attention with a visual image, and involving an emotional transformation process leading to emotional energy and enactment.

\section{CONCLUSION}

Visual symbols, and the emotional energy they create, have, by their absence in the management literature, limited the problems and the solutions we see, and limited our understanding of what drives people to address grand challenges by doing difficult and counterintuitive things. In a world in which scientists are no longer believed, the climate change that is threatening our survival is doubted, and "fake news" abounds, cynicism and inaction are the easier path. In such a world, visual images still have the potential to move us beyond cynicism to action, by evoking emotions that social entrepreneurs can use to build our emotional energy for action. Visuals like the albatross photos and videos bring us into relation with non-human nature, mattering nature in a way that scientific text does not, making us see, feel and be in new ways. While the albatross symbol elicits grief and rage, it also elicits compassion and hope for the future, which "dwells in the human capacity to regard, to touch, to affect, to care" (Wagner-Lawlor, 2016: 685). In the face of societal grand challenges (Ferraro, Etzion \& Gehman, 2015), visual symbols have a significant potential to affect people, to charge them with emotional energy, to make them identify, socially and morally with others, and then to move them to action. Emotion-symbolic work calls our attention to the ways leaders and entrepreneurs use symbols to evoke this energy 
and enactment.

\section{ACKNOWLEDGEMENTS}

We are very grateful to the deputy editor Marc Gruber and three anonymous reviewers for their thoughtful guidance and insightful comments. We appreciate the detailed feedback from Arturo Álvarez-Roldán, Shaz Ansari, Daniel Beunza, Marina Calvo, Iván Cuesta, Olga Fernández, Raghu Garud, Joel Gehman, Bryant Hudson and Renate Meyer and the generous support of Kellie McElhaney, Mette Morsing and Woody Powell during the course of writing this paper. Earlier versions of this paper were presented at the annual meeting of the Academy of Management in Vancouver (where it was awarded with the Best OMT Entrepreneurship Paper award), the European Group of Organization Studies Colloquium in Naples and Rotterdam, Cornell's SC Johnson College of Business JCB/ILR M\&O Workshop at Cornell University, the Litem Seminar Series at Institut Mines-Télécom Business School in Paris, KIN Center for Digital Innovation and Department of Organization Science at VU University Amsterdam, Grenoble Ecole de Management, IESEG School of Management, Instituto Interuniversitario López Piñero and Llibrería Ramón Llull in Valencia. We thank all the participants for their comments and suggestions. Any inaccuracies or omissions are entirely our own. 


\section{REFERENCES}

Allison, G. T. 1971. Essence of Decision. Boston, MA: Little, Brown.

Aminzade, R., \& McAdam, D. 2002. Emotions and contentious politics. Mobilization, 7: 107-109.

Appel, H., Gerlach, A. L., \& Crusius, J. 2016. The interplay between Facebook use, social comparison, envy, and depression. Current Opinion in Psychology, 9: 44-49.

Arend, R. J. 2013. A heart-mind-opportunity nexus: Distinguishing social entrepreneurship for entrepreneurs. Academy of Management Review, 38: 313-315.

Austin, J., Stevenson, H., \& Wei-Skillern, J. 2006. Social and commercial entrepreneurship: same, different, or both? Entrepreneurship Theory and Practice, 30: 1-22.

Bacq, S., \& Alt, E. 2018. Feeling capable and valued: A prosocial perspective on the link between empathy and social entrepreneurial intentions. Journal of Business Venturing, 33: 333350.

Barthes, R. 1977. Image, Music, Text. New York, NY: Hill and Wang.

Bassett, D. 2010. Breaking the plastic addiction: TEDx Great Pacific Garbage Patch, Huffington Post. http://www.huffingtonpost.com/deborah-bassett/breaking-the-plasticaddi_b_781569.html, retrieved $10^{\text {th }}$ January 2015 .

Boxenbaum, E., Jones, C., Meyer, R. E., \& Svejenova, S. 2018. Towards an articulation of the material and visual turn in organization studies. Organization Studies, 39: 597-616.

Bunderson, J. S., \& Thompson, J. A. 2009. The call of the wild: Zookeepers, callings, and the double-edged sword of deeply meaningful work. Administrative Science Quarterly, 54: 32-57.

Cardon, M. S., Foo, M. D., Shepherd, D., \& Wiklund, J. 2012. Exploring the heart: Entrepreneurial emotion is a hot topic. Entrepreneurship Theory and Practice, 36: 1-10.

Cardon, M. S., Glauser, M., \& Murnieks, C. Y. 2017. Passion for what? Expanding the domains of entrepreneurial passion. Journal of Business Venturing Insights, 8: 24-32.

Cardon, M. S., Zietsma, C., Saparito, P., Matherne, B. P., \& Davis, C. 2005. A tale of passion: New insights into entrepreneurship from a parenthood metaphor. Journal of Business Venturing, 20: 23-45.

Cartel, M., Boxenbaum, E., \& Aggeri, F. 2019. Just for fun! How experimental spaces stimulate innovation in institutionalized fields. Organization Studies, 40: 65-92.

Castelló, I., Etter, M., \& Nielsen, F. A. 2016. Strategies of legitimacy through social media: The networked strategy. Journal of Management Studies, 53: 402-432.

Chapman, D. A., Corner, A., Webster, R., \& Markowitz, E. M. 2016. Climate visuals: A mixed 
methods investigation of public perceptions of climate images in three countries. Global Environmental Change, 41: 172-182.

Charmaz, K. 2014. Constructing Grounded Theory ( $2^{\text {nd }}$ ed). Los Angeles, CA: Sage.

Chen, X. P., Yao, X., \& Kotha, S. 2009. Entrepreneur passion and preparedness in business plan presentations: A persuasion analysis of venture capitalists' funding decisions. Academy of Management Journal, 52: 199-214.

Christensen, L. H. 2018. The use of visuals in issue framing: Signifying responsible drinking. Organization Studies, 39: 665-689.

Clarke, J. 2011. Revitalizing entrepreneurship: How visual symbols are used in entrepreneurial performances. Journal of Management Studies, 48: 1365-1391.

Collins, R. 2004. Interaction Ritual Chains. New Haven, CT: Princeton University Press.

Delmestri, G., \& Goodrick, E. 2016. Looking away: Denial and emotions in institutional stability and change. Research in the Sociology of Organizations, 48A: 235-274.

Dencik, L., \& Allan, S. 2017. In/visible conflicts: NGOs and the visual politics of humanitarian photography. Media, Culture \& Society, 39: 1178-1193.

DiMaggio, P. J. 1988. Interest and agency in institutional theory. In: L. Zucker (Ed.), Institutional Patterns and Culture: 3-21. Cambridge, MA: Ballinger.

DG Environment. 2011. Plastic waste: Ecological and human health impacts. In: S. f. E. Policy (Ed.), News Alert Service, In-depth Report. Brussels, European Commission's Directorate-General Environment.

Doerr, N., Mattoni, A., \& Teune, S. 2013. Visuals in social movements. In: D. della Porta \& M. Diani (Eds.), The Oxford Handbook of Social Movements: 557-566. Oxford, UK: Oxford University Press.

Durand, R., \& Paolella, L. 2013. Category stretching: Reorienting research on categories in strategy, entrepreneurship, and organization theory. Journal of Management Studies, 50: 1100-1123.

Elias, S. R., Chiles, T. H., Duncan, C. M., \& Vultee, D. M. 2018. The aesthetics of entrepreneurship: How arts entrepreneurs and their customers co-create aesthetic value. Organization Studies, 39: 345-372.

Eriksen, M., Lebreton, L. C., Carson, H. S., Thiel, M., Moore, C. J., Borerro, J. C., \& Reisser, J. 2014. Plastic pollution in the world's oceans: More than 5 trillion plastic pieces weighing over 250,000 tons afloat at sea. PloS one, 9(12): e111913.

Eyerman, R. 2005. How social movements move: Emotions and social movements. In: H. Flam \& D. King (Eds.), Emotions and Social Movements: 41-56. London: Routledge. 
Fan, G. H., \& Zietsma, C. 2017. Constructing a shared governance logic: The role of emotions in enabling dually embedded agency. Academy of Management Journal, 60: 2321-2351.

Farny, S., Kibler, E., \& Down, S. forthcoming. Collective emotions in institutional creation work. Academy of Management Journal. doi.org/10.5465/amj.2016.0711

Fehrenbach, H., \& Rodogno, D. 2015. “A horrific photo of a drowned Syrian child”: Humanitarian photography and NGO media strategies in historical perspective. International Review of the Red Cross, 97: 1121-1155.

Friedland, R. 2018. Moving institutional logics forward: Emotion and meaningful material practice. Organization Studies, 39: 515-542.

Ferraro, F., Etzion, D., \& Gehman, J. 2015. Tackling grand challenges pragmatically: Robust action revisited. Organization Studies, 36: 363-390.

Gill, M. J., \& Burrow, R. 2018. The function of fear in institutional maintenance: Feeling frightened as an essential ingredient in haute cuisine. Organization Studies, 39: 445-465.

Gioia, D., Corley, K., \& Hamilton, A. 2013. Seeking qualitative rigor in inductive research: Notes on the Gioia methodology. Organizational Research Methods, 16: 15-31.

Gioia, D. A., Thomas, J. B., Clark, S. M., \& Chittipeddi, K. 1994. Symbolism and strategic change in academia: The dynamics of sensemaking and influence. Organization Science, 5: 363383.

Giorgi, S. 2017. The mind and heart of resonance: The role of cognition and emotions in frame effectiveness. Journal of Management Studies, 54: 712-738.

Goodwin, J., \& Jasper, J. M. 2006. Emotions and social movements. In: J. E. Stets (Ed.), Handbook of the Sociology of Emotions: 611-635. Boston, MA: Springer.

Goodwin, J., Jasper, J. M., \& Polletta, F. (Eds.) 2001. Passionate Politics: Emotions and Social Movements. Chicago, IL: University of Chicago Press.

Goss, D. 2008. Enterprise ritual: A theory of entrepreneurial emotion and exchange. British Journal of Management, 19: 120-137.

Gray, B., Purdy, J. M., \& Ansari, S. 2015. From interactions to institutions: Microprocesses of framing and mechanisms for the structuring of institutional fields. Academy of Management Review, 40: 115-143.

Greenwood, R., Suddaby, R., \& Hinings, C. R. 2002. Theorizing change: The role of professional associations in the transformation of institutionalized fields. Academy of Management Journal, 45: 58-80.

Grimes, M. G., McMullen, J. S., Vogus, T. J., \& Miller, T. L. 2013. Studying the origins of social entrepreneurship: Compassion and the role of embedded agency. Academy of 
Management Review, 38: 460-463.

Haidt, J. 2003. The moral emotions. In R. J. Davidson, K. R. Sherer, \& H. H. Goldsmith (Eds.), Handbook of Affective Sciences: 852-870. Oxford, UK: Oxford University Press.

Hambrick, D. C., \& Lovelace, J. B. 2018. The role of executive symbolism in advancing new strategic themes in organizations: A social influence perspective. Academy of Management Review, 43: 110-131.

Hatten, M. L. 1982. Strategic management in not-for-profit organizations. Strategic Management Journal, 3: 89-104.

Hiatt, S. R., Sine, W. D., \& Tolbert, P. S. 2009. From Pabst to Pepsi: The deinstitutionalization of social practices and the creation of entrepreneurial opportunities. Administrative Science Quarterly, 54: 635-667.

Hochschild, A. R. 1979. Emotion work, feeling rules, and social structure. American Journal of Sociology, 85: 551-575.

Hoffman, A. J. 2011. Talking past each other? Cultural framing of skeptical and convinced logics in the climate change debate. Organization \& Environment, 24: 3-33.

Höllerer, M. A., Jancsary, D., \& Grafström, M. 2018. 'A picture is worth a thousand words': Multimodal sensemaking of the global financial crisis. Organization Studies, 39: 617-644.

Jarvis, L., Goodrick, E., \& Hudson, B. A. forthcoming. Where the heart functions best: Reactiveaffective conflict and the disruptive work of animal rights organizations. Academy of Management Journal. doi: 10.5465/amj.2017.0342

Jasper, J. M. 2008. The Art of Moral Protest: Culture, Biography, and Creativity in Social Movements. Chicago, IL: University of Chicago Press.

Jasper, J. M. 2011. Emotions and social movements: Twenty years of theory and research. Annual Review of Sociology, 37: 285-303.

Jasper, J. M., \& Poulsen, J. D. 1995. Recruiting strangers and friends - moral shocks and social networks in animal rights and antinuclear protests. Social Problems, 42: 493-512.

Jennings, J. E., Edwards, T., Jennings, P. D., \& Delbridge, R. 2015. Emotional arousal and entrepreneurial outcomes: Combining qualitative methods to elaborate theory. Journal of Business Venturing, 30: 113-130.

Joffe, H. 2008. The power of visual material: Persuasion, emotion and identification. Diogenes, 55: 84-93.

Jones, C., \& Massa, F. G. 2013. From novel practice to consecrated exemplar: Unity temple as a case of institutional evangelizing. Organization Studies, 34: 1099-1136. 
Kaplan, S. 2008. Framing contests: Strategy making under uncertainty. Organization Science, 19: 729-752.

Khaire, M., \& Wadhwani, R. D. 2010. Changing landscapes: The construction of meaning and value in a new market category-Modern Indian art. Academy of Management Journal, 53: 1281-1304.

Kozinets, R. 2002. The field behind the screen: Using netnography for marketing research in online communities. Journal of Marketing Research, 39: 61-72.

Kramer, A. D. I., Guillory, J. E., \& Hancock, J. T. 2014. Experimental evidence of massive-scale emotional contagion through social networks. Proceedings of the National Academy of Sciences, 111: 8788-8790.

Kress, G., \& Van Leeuwen, T. 2006. Reading Images: The Grammar of Visual Design. London, UK: Routledge.

Langer, S. 1951. Philosophy in a New Key. New York, NY: Mentor Books.

Lawrence, T. B., \& Buchanan, S. 2017. Power, institutions and organizations. In: R. Greenwood, C. Oliver, T. Lawrence \& R. Meyer (Eds.), Handbook of Organizational Institutionalism: 477-506. London, UK: Sage.

Lawrence, T. B., \& Phillips, N. 2019. Constructing organizational life: How social-symbolic work shapes selves, organizations, and institutions. Oxford, UK: Oxford University Press

Lefsrud, L., Graves, H., \& Phillips, N. 2015. Analyzing visual rhetoric in organizational research. In: K. Elsbach \& R. Kramer (Eds.), Handbook of Qualitative Organizational Research: Innovative Pathways and Methods: 225-237. New York, NY: Routledge.

Lincoln, Y. S., \& Guba, E. G. 1985. Naturalistic Inquiry. Thousand Oaks: Sage.

Lounsbury, M., \& Glynn, M. A., 2001. Cultural entrepreneurship: Stories, legitimacy, and the acquisition of resources. Strategic Management Journal, 22: 545-564.

Mair, J., \& E. Noboa. 2006. Social entrepreneurship: How intentions to create a social venture are formed. In: J. Mair, J. A. Robinson \& K. Hockerts (Eds.), Social Entrepreneurship: 121135. Basingstoke, UK: Palgrave Macmillan.

Maitlis, S., \& Lawrence, T. B. 2007. Triggers and enablers of sensegiving in organizations. Academy of Management Journal, 50: 57-84.

Massa, F. G., Helms, W. S., Voronov, M., \& Wang, L. 2017. Emotions uncorked: Inspiring evangelism for the emerging practice of cool-climate winemaking in Ontario. Academy of Management Journal, 60: 461-499.

Mattoni, A., \& Teune, S. 2014. Visions of protest. A media-historic perspective on images in social movements. Sociology Compass, 8: 876-887. 
McLaren, K. 2013. The emotional imperative of the visual: Images of the fetus in contemporary Australian pro-life politics. Research in Social Movements, Conflicts and Change, 35: 81-103.

Meyer, R. E., Höllerer, M. A., Jancsary, D., \& Van Leeuwen, T. 2013. The visual dimension in organizing, organization, and organization research: Core ideas, current developments, and promising avenues. Academy of Management Annals, 7: 487-553.

Meyer, R. E., Jancsary, D., Höllerer, M. A., \& Boxenbaum, E. 2018. The role of verbal and visual text in the process of institutionalization. Academy of Management Review, 43: 392-418.

Miller, T. L., Grimes, M. G., McMullen, J. S., \& Vogus, T. J. 2012. Venturing for others with heart and head: How compassion encourages social entrepreneurship. Academy of Management Review, 37: 616-640.

Moisander, J. K., Hirsto, H., \& Fahy, K. M. 2016. Emotions in institutional work: A discursive perspective. Organization Studies, 37: 963-990.

Moon, D. 2013. Powerful emotions: Symbolic power and the (productive and punitive) force of collective feeling. Theory and Society, 42: 261-294.

Moore, C. 2012. Plastic Ocean: How a Sea Captain's Chance Discovery Launched a Determined Quest to Save the Oceans. New York, NY: Penguin.

Mortensen, M., Allan, S., \& Peters, C. 2017. The iconic image in a digital age. Editorial mediations over the Alan Kurdi photographs. Nordicom Review, 38: 71-86.

Navis, C., \& Glynn, M. A. 2010. How new market categories emerge: Temporal dynamics of legitimacy, identity, and entrepreneurship in satellite radio, 1990-2005. Administrative Science Quarterly, 55: 439-471.

Neilson, A. 2018. Considering the importance of metaphors for marine conservation. Marine Policy. doi: 10.1016/j.marpol.2018.03.019.

Nisbet, M. C. 2009. Communicating climate change: Why frames matter for public engagement. Environment: Science and Policy for Sustainable Development, 51: 12-23.

O’Neill, S. J., \& Nicholson-Cole, S. 2009. "Fear won't do it": Promoting positive engagement with climate change through visual and iconic representations. Science Communication, 30: 355-379.

O’Neill, S. J., \& Smith, N. 2014. Climate change and visual imagery. WIREs Climate Change, 5: 73-87.

Patton, M. Q. 2002. Qualitative Research \& Evaluation Methods. Thousand Oaks, CA: Sage.

Phillips, N., \& Lawrence, T. B. 2012. The turn to work in organization and management theory: Some implications for strategic organization. Strategic Organization, 10: 223-230. 
Polletta, F., \& Jasper, J. M. 2001. Collective identity and social movements Annual Review of Sociology, 27: 283-305.

Quinn, R. W., \& Dutton, J. E. 2005. Coordination as energy-in-conversation. Academy of Management Review, 30: 36-57.

Rafaeli, A., \& Sutton, R. I. 1987. Expression of emotion as part of the work role. Academy of Management Review, 12: 23-37.

Rao, H. 1998. Caveat emptor: The construction of nonprofit consumer watchdog organizations. American Journal of Sociology, 103: 912-961.

Rao, H., \& Giorgi, S. 2006. Code breaking: How entrepreneurs exploit cultural logics to generate institutional change. Research in Organizational Behavior, 27: 269-304.

Rao, H., Morrill, C., \& Zald, M. 2000. Power plays: How social movements and collective action create new organizational forms. Research in Organizational Behavior, 22: 237-281.

Reger, J. 2004. Organizational "emotion work" through consciousness-raising: An analysis of a feminist organization. Qualitative Sociology, 27: 205-222.

Ruebottom, T., \& Auster, E. 2018. Reflexive dis/embedding: Personal narratives, empowerment and the emotional dynamics of interstitial events. Organization Studies, 39: 467-490.

Rynes, S. L., Bartunek, J. M., Dutton, J. E., \& Margolis, J. D. 2012. Care and compassion through an organizational lens: Opening up new possibilities. Academy of Management Review, 37: 503-523.

Scheff, T. J. 2007. Politics of hidden emotions: Responses to a war memorial. Peace and Conflict: Journal of Peace Psychology, 13: 237-246.

Shepherd, D. A., \& Williams, T. A. 2014. Local venturing as compassion organizing in the aftermath of a natural disaster: The role of localness and community in reducing suffering. Journal of Management Studies, 51: 952-994.

Smith, A. D. 2002. From process data to publication: A personal sensemaking. Journal of Management Inquiry, 11: 383-406.

Sonenshein, S. 2006. Crafting social issues at work. Academy of Management Journal, 49: 11581172 .

Staggenborg, S. 2013. Entrepreneurs, movement. In: D. A. Snow, D. Della Porta, B. Klandermans \& D. McAdam (Eds.), The Wiley-Blackwell Encyclopedia of Social and Political Movements. Malden, MA: Blackwell.

Strauss, A., \& Corbin, J. 1990. Basics of Qualitative Research: Grounded Theory Procedures and Techniques. Newbury Park, CA: Sage. 
Suddaby, R., \& Greenwood, R. 2005. Rhetorical strategies of legitimacy. Administrative Science Quarterly, 50: 35-67.

Tangney, J. P., \& Dearing, R. L. 2003. Shame and Guilt. New York, NY: Guilford Press.

Tarrow, S. 2010. Power in Movement: Collective Action, Social Movements and Politics: Cambridge, UK: Cambridge University Press.

Taylor, V., \& Rupp, L. 2002. Loving internationalism: The emotion culture of transnational women's organizations, 1888-1945. Mobilization, 7: 141-158.

Terry, B., 2012. Plastic Free: How I Kicked the Plastic Habit and How You Can Too. San Francisco, CA: Skyhorse.

Thorgren, S., \& Omorede, A. 2018. Passionate leaders in social entrepreneurship: Exploring an African context. Business \& Society, 57: 481-524.

Tracey, P. 2016. Spreading the word: The microfoundations of institutional persuasion and conversion. Organization Science, 27: 989-1009.

Toubiana, M., \& Zietsma, C. 2017. The message is on the wall? Emotions, social media and the dynamics of institutional complexity. Academy of Management Journal, 60: 922-953.

Van Cauwenberghe, L., \& Janssen, C. R. 2014. Microplastics in bivalves cultured for human consumption. Environmental Pollution, 193: 65-70.

Van Leeuwen, T. 2005. Multimodality, genre and design. In: S. Norris \& R. H. Jones (Eds.), Discourse in Action: Introducing Mediated Discourse Analysis: 73-95. London, UK: Routledge.

Vatrapu, R. 2013. Understanding social business. In: K. B. Akhilesh (Ed.), Emerging Dimensions of Technology Management: 147-158. New Delhi: Springer.

Vesa, M., \& Vaara, E. 2014. Strategic ethnography 2.0: Four methods for advancing strategy process and practice research. Strategic Organization, 12: 288-298.

Voronov, M., \& Weber, K. 2016. The heart of institutions: Emotional competence and institutional actorhood. Academy of Management Review, 41: 456-478.

Wakefield, A., \& Fleming, J. 2009. Responsibilization. In The SAGE Dictionary of Policing (pp. 277-278). London, UK: Sage.

Wagner-Lawlor, J. A. 2016. Regarding intimacy, regard, and transformative feminist practice in the art of Pamela Longobardi. Feminist Studies, 42: 649-688.

Weber, K., Heinze, K. L., \& DeSoucey, M. 2008. Forage for thought: Mobilizing codes in the movement for grass-meat and dairy products. Administrative Science Quarterly, 53: 529567. 
Wettergren, ̊. 2005. Mobilization and the moral shock: Adbusters Media Foundation. In: H. Flam \& D. King (Eds.), Emotions and Social Movements: 99-118. London, UK: Routledge.

Wickert, C., \& de Bakker, F. G. A. 2018. Pitching for social change: Towards a relational approach to selling and buying social issues. Academy of Management Discoveries, 4: 50-73.

Wry, T., Lounsbury, M., \& Glynn, M. A. 2011. Legitimating nascent collective identities: Coordinating cultural entrepreneurship. Organization Science, 22: 449-463.

Zamparini, A., \& Lurati, F. 2017. Being different and being the same: Multimodal image projection strategies for a legitimate distinctive identity. Strategic Organization, 15: 6-39.

Zilber, T. B. 2011. Institutional multiplicity in practice: A tale of two high-tech conferences in Israel. Organization Science, 22: 1539-1559.

Zott, C., \& Huy, Q. N. 2007. How entrepreneurs use symbolic management to acquire resources. Administrative Science Quarterly, 52: 70-105. 
TABLES AND FIGURES

Table 1: Summary of Data Sources and Analysis

\begin{tabular}{|c|c|c|}
\hline Data Source & Type of Data & Use in the Analysis \\
\hline $\begin{array}{l}\text { Naturalistic } \\
\text { Observation }\end{array}$ & $\begin{array}{l}\text { 08-2010 to 04-2011 \& } 06-2013 \text { to } 9-2013 \text { in California. } \\
\text { - } 7 \text { social gatherings and art exhibitions ( } 28 \mathrm{~h}) \\
\text { - } 2 \text { workshops (6h), TED talks ( } 29 \text { transcribed presentations) } \\
\text { - } 5 \text { meetings with PPC leaders ( } 7 \mathrm{~h})\end{array}$ & $\begin{array}{l}\text { - Development of the historical account (key actors, key organizations and main activities, } \\
\text { movement configuring events) } \\
\text { - Characterization of the cause } \\
\text { - Triangulation to identify patterns, consistencies and inconsistency }\end{array}$ \\
\hline $\begin{array}{l}\text { Semi- } \\
\text { structured } \\
\text { Interviews }\end{array}$ & $\begin{array}{l}\text { 08- 2010- 09-2018 (Total 1,789 minutes transcribed) } \\
\text { - People involved in the NPO as founders, staff or advisors } \\
\text { (20 interviews) } \\
\text { - Managers of key NGOs (14 interviews) } \\
\text { - Targeted actors including local leaders (16 interviews) }\end{array}$ & $\begin{array}{l}\text { - Development of a historical account of the movement (actors, organizations, activities, events) } \\
\text { - Detailed understanding of interactions of entrepreneurs and other actors with symbols and } \\
\text { characterization of the relation } \\
\text { - Characterization of the cause; Understanding of rational and strategic intent } \\
\text { - Characterization of visibility and impact achieved over time }\end{array}$ \\
\hline Archives & $\begin{array}{l}\text { - } 44 \text { documents including strategic plans, websites, emails, } \\
\text { newsletters, articles, press articles } \\
\text { - } 2 \text { Books (Moore, 2012; Terry, 2012) } \\
\text { - } 5 \text { documentaries: Albatross, Blue Planet II (Ch. 1\&7, clip } \\
\text { on plastics, Message in the Waves (225 minutes) }\end{array}$ & $\begin{array}{l}\text { - Understanding of strategic intent } \\
\text { - Development of historical account of the movement and its impact over time } \\
\text { - Deeper understanding of the issue of plastic pollution and its evolution } \\
\text { - Deeper understanding of the use of the symbols and the emotional energy generated in } \\
\text { entrepreneurs and other actors }\end{array}$ \\
\hline \multicolumn{3}{|l|}{ Social Media } \\
\hline Facebook & $\begin{array}{l}\text { - Observations from } 6 \text { key Facebook pages } \\
\text { - Systematic analysis of NPO Facebook page } 10-2009 \text { to } 12 \text { - } \\
\text { 2011. Total of } 17,287 \text { lines, including } 578 \text { posts, } 2,504 \\
\text { comments on these posts, selected } 421 \text { exchanges } \\
\text { - Analysis of NPO Facebook page from } 2012 \text { to } 2018 \text { and } \\
\text { selection of key images and text }\end{array}$ & $\begin{array}{l}\text { - Characterization of emotion-symbolic work } \\
\text { - Characterization of the emotional energy } \\
\text { - Deeper understanding of the creation of identification and find evidence of enactment of } \\
\text { the cause } \\
\text { - Understanding of the nature of the relation between entrepreneurs and other actors }\end{array}$ \\
\hline Twitter & $\begin{array}{l}\text { - } 8 \text { key hashtags and } 3 \text { accounts reviewed: } \\
\text { Tweets read: } 4,517 \text {. Specific analysis of Tweets with } 2 \text { or } \\
\text { more comments selected: } 628 \text { comments analysed }\end{array}$ & $\begin{array}{l}\text { - Characterization of emotional energy and emotion-symbolic work } \\
\text { - Understanding of the creation of identification; evidence of enactment } \\
\text { - Understanding of the nature of the relation between entrepreneurs and other actors }\end{array}$ \\
\hline Instagram & $\begin{array}{l}\text { - } 23 \text { hashtags and accounts reviewed: Total exchanges } \\
\text { analyzed: } 33 \text { ranging from } 2 \text { to } 36 \text { lines each }\end{array}$ & $\begin{array}{l}\text { - Characterization of emotional energy } \\
\text { - Understanding of the creation of identification; evidence of enactment }\end{array}$ \\
\hline $\begin{array}{l}\text { Blogs and } \\
\text { Mass Media } \\
\text { Web Sites }\end{array}$ & $\begin{array}{l}\text { Systematic analysis of the comments in two sites: } \\
\text { - YouTube video on Midway: } 252 \text { comments } \\
\text { - The Guardian chat: } 319 \text { comments }\end{array}$ & $\begin{array}{l}\text { - Understanding of the emotional reaction of the publics to the images, not mediated by the } \\
\text { NPO social entrepreneurs }\end{array}$ \\
\hline
\end{tabular}


Table 2. Emotion-symbolic Work: Aggregate Themes, First-Order Constructs, Empirical Themes and Data Examples

\section{SYMBOL PRODUCTION AND DIFFUSION}

\section{First-order Empirical Themes and Examples from Data}

Constructs

Symbol

Production

Experiencing Moral Shock: "I had rescued so many birds ... I'm just ploughing into the waves getting these birds back out. They're big birds but when you lift them up you can sort of tell if they're dead already. I lifted on bird and she actually had some weight about her and she turned around and pecked me on my hand and I've still got the scar today on my hand and its sort of a little reminder of all of this." (Betty, 2018)

- "I found the story and learned babies where dying because of what the parents were feeding to the babies. This created a huge personal relevance to me. A lot of the plastic could have come from my kitchen and from my home. As a mother, I felt a huge amount of responsibility and I connected as a mother ... I'm not giving poison to my children. It became personal relevance ...You feel you need to share with the world.” (Diane, 2011)

Theorizing: "In a way the Midway journey is about stopping the consumption of plastic and in other hand is how is that humanity is going to face the truth of our times, the horrors of the world that we have to do if we are going to solve them. How are we going to face those horrors and maintain the sense of individual empowerment and hope?" (Chris, 2010)

- "Who could imagine that this island, in the middle of nowhere, was going to be the starting point of many things?" (Chris, 2010)

Symbol

Diffusion

Engaging in Multimodal Conversations: "I started to talk to people about it... We start to connect with Charlie Moore, share stories and information with the public. Along the same lines Social media was invented... the social aspect was that I shared emails and how people responded. It was web 1.0 try to become 2.0 , the ability to create communities it was natural." (Will, 2011)

- "For me I noticed that it was very important, blogs with better response where I was very personal and I talked about my struggles ... The posts with information are valuable but they don't engage people. I feel is important get people engage in discussing." (Barbara, 2011)

Social Media Diffusion: “Depending on what mode of communication I will target different groups...” (Will, 2011)

- "It was very successful, lots of different strategies: contacting organizations, contacting bloggers, media, Facebook, Twitter other bloggers... The strategy to reach a broader audience is to connect on the web with other people that were already on the web." (Barbara, 2011)

\section{EMOTION-SYMBOLIC WORK TO EMBED TARGET ACTORS INTO THE MOVEMENT USING THE SYMBOL}

Connecting to the Cause
Anchoring: "It makes me realize how every day, the things we use every day, plastic is everywhere, plastic is so intertwined with the things we do. You cannot escape, the image is shocking and brutal, which is why it works." (Toni, 2018) 
- FB-04-2010-NPO: "strange metaphor that the ocean has become our blue bin. Stopping this at the source is the only way."

Responsibilizing: FB-04-2010-NPO: "Let's not finger wag. We all killed this whale. We are all together in this, and we will leave the plastic age together or not at all. Let's help each other understand what plastic does to the planet and to the health of animals, such as whales or albatrosses. As more and more people wake up from the plastic matrix, change will keep on spreading throughout the world. Onward!'”

- "So we started with lighters. Then...let's do the golf balls next and then...if you brush your hair here's a comb, and here's all the toys and then we were ending up with the toothbrushes because everyone uses a toothbrush." (Betty, 2018)

Connecting to an Promoting Solidarity: FB-07-2010-NPO: “Alma: Those pics are so sad

Emerging

NPO: Alma, I feel deep sorrow too, every day. Please don't give up/shut-down. We need everyone that is capable of having such empathy..."

Collective

- "I want people to watch this film and feel sadness and rage and realize that comes from a place of love. Don't pull the plug... don't let all that raw emotion drain away. Once you feel love, you can be more courageous and make more radical choices." (Chris, The Guardian, 2018)

Promoting Hope in the Efficacy of Collective Action: FB-04-2010-NPO: "Could some scientist please explain why marine scientists study what they study? Science is based in doubt, which is good for method, but can be harmful to society if it leads to paralysis...cannot wait for autopsies of each and every whale that dies stuffed with plastic garbage. It is certain that some of our most majestic animals, such as albatrosses and whales are dying stuffed with plastic garbage...here's something that is certain to everyone: whales should not be eating plastic bags. People, we can STOP using plastic bags NOW! Bring your own! Refuse! Fight on!"

- "I find sharing the objects I find online, through social media, the use of hashtags has been fantastic to connect up with other people that are collecting and also doing beach cleans. There is a real online community of people who are able to help you identify the objects that you find, the things that I use in my work. Also, it fosters a sense of that collective identity because it's the objects that are the foundation of our community and enable me to make those connections." (Janette, 2018)

Connecting to

the Social

Establishing the NPO's Legitimacy: FB-03-2010-NPO: "Here's some reading that might be helpful: http://npo.org/learn/basic-concepts/ and http://npo.org/learn/avoiding-the-pitfalls/"'

Entrepreneurs

- "We share our coalition member's videos, we do original blog posts and also all types of social media posts...we try to really educate and inspire our followers to change behavior around single use plastic." (Helena, 2018)

Establishing the Social Entrepreneurs' Influence': FB-03-2010-NPO: “And a video to watch -where you can put a face to the person writing these lines- http://www.youtube.com/watch? It was filmed on Midway Atoll, near the heart of the so called Pacific garbage patch. Thank you so much Tim. We are together in this. Onward."

- "I got them all to watch the film and then I explained my little idea and I said, look it's up to you, but what I had was I already had got the gem in the back of I got Simon the butcher already to agree..." (Betty, 2018) 
Table 3. Reactions of Target Actors: Aggregate Themes, First-Order Constructs, Empirical Themes and Data Examples

\begin{tabular}{|c|c|}
\hline $\begin{array}{l}\text { First-order } \\
\text { Constructs }\end{array}$ & Empirical Themes and Examples from Data \\
\hline Moral Shock & $\begin{array}{l}\text { Sadness: INS-04-2018: “@blueP "Dr. Sagan at Midway Island emptying the stomach contents of a Laysan Albatross So sad!!! } \\
\text { Pipi: So sad.” } \\
\text { - "I remember just shortly after coming to [NPO] in 2016, seeing Chris Jordan's photo of the albatross with the stomach full of plastic and it was just very, } \\
\text { very compelling and horribly sad.” (Helena, 2018) }\end{array}$ \\
\hline
\end{tabular}

Rage: FB-08-2010-Cynthia: "It's gross Really opens your eyes I...don't throw my rubbish about or abandon it willy nilly. Ppl need 2 think \& dispose of their trash in a responsible manner."

- FB-05-2010-Christopher: "Paradise Bali....now walking in true garbage, surfing in garbage and probably eating garbage! but how do we solve problems as drinking water over there to minimize bottled beverage?"

Despair: "I felt disgusted and helpless...you see a problem as...something that we can stop, and when you see a picture like that and you realize that it's too late for anything to really happen, it's already been ingested, it's already killing animals..." (Carsten, 2018)

- "Yeah, I think I just remember a moment of shock and revulsion when I first saw." (Janette, 2018)

\section{TARGET ACTORS' EMOTIONAL ENERGY}

Energetic Individual Motivation: "[the symbol is the] energy that is going to move any kind of call to action. That energy can be intellectual, but that does not go Arousal very far. What moves us is passion." (Max, 2018)

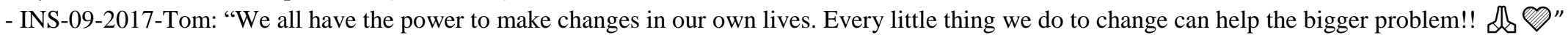

Collective Excitement: Blog-05-2018-Peter: "Me and my class were very motivated by this and want to help out."

- INS-01-2018-chrisjordan_albatross: "Having a fantastic and transformative time with all of my new friends here in Santiago, the Congresso Futuro was beyond inspiring.

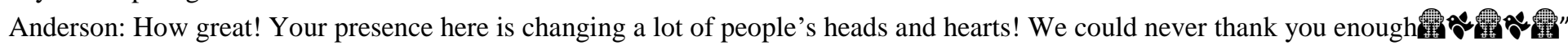


Identification Collective Identification: FB-06-2010-Barbara: "So shocking! Everybody has to see that video to become aware of the impact of plastic."

- "The film was following a baby albatross full of plastic...I found the story and learned babies where dying because of what the parents were feeding to the babies. This created a huge personal relevance to me. A lot of the plastic could have come from my kitchen and from my home. As a mother, I felt a huge amount of responsibility and I connected as a mother...I'm not giving poison to my children. It became personal relevance... You feel you need to share with the world...I also want to help the other people to live without plastic." (Diane, 2011)

Organizational Attachment: FB-06-2010-Fighters: "We get lot of inspiration from Plastic Pollution Coalition! Great work NPO team!"

- "I think [the albatross symbol] has quite an enormous role in this...plastic pollution in the ocean and it wasn't until he took those pictures of those chicks and other young birds with their stomachs filled with plastic that-I mean like that picture is worth a thousand words and those images really shocked people, it woke people up, and got a lot of people concerned. I feel like...the NGO...they sort of focus...systematically at the is sue.” (Alexandra, 2013)

\section{Moral}

Emotions

Internalizing the Cause: "The albatross... (has a) high merit for conveying to people the beauty and intricacy of our natural world, to stimulate a sense of belonging to this natural world on our planet and to experience a desire to protect it and to respect the life of this planet earth." (Miriam, 2018)

- INS-01-2018-chrisjordan_albatross: "Albie ready to rock Harvard Univ this week. : )

Matt: Your Instagram feed is inspiring us to chasing after adventure! Thanks for sharing 8

June: Can't wait to see this again at University of Washington! A life-changing film experience ."

Feeling Indignation: FB-04-2010-Sandra: “This plastic problem we've created is just as deadly as The Oil Eruption...Thank you for keeping this issue 'in our faces'!!!"

- FB-09-2010-Mathew: "Wow, what a powerful juxtaposition between life and death (horrid, needless death human-caused). we are indeed destroying our planet from every angle. you don't have to have much of imagination to be able to see the tern chick as a human child today, teetering on the edge of a raft of death entirely of our own creation."

\section{TARGET ACTORS' ENACTMENT OF THE CAUSE}

Enactment of

the cause

Pledging to Act FB-06-2010-Mimi: "I go to our local beach a lot. Tonight, for Solstice, I am beginning my clean-up...bringing a couple of recycled bags to fill with beach plastic...let's get what's there out bit by bit."

- "I remember when talking with the hotel manager, after telling him about the straws and how they do not biodegrade, he called somebody and say: we have to order paper straws." (Toni, 2018)

Performing the Cause "It definitely was one of the more depressing and disturbing pictures I'd ever come across and all it did was raise a ton of questions for me. It ended up helping, actually, influence my path into going into plastic pollution." (Carsten, 2018)

- "I've been doing conferences in the Schools Global Network around the world. Children always have an immediate reaction to the picture. In Lima...they installed fountains in the school and have a meter to measure the number of bottles they are saving. In other schools the kids make designs of the albatross and when you ask them, what are you going to do? They answer: not to use anymore plastic." (Colin, 2018)

Evangelizing INS-11-2017-John: "been showing the video to my students in Korea and Indonesia since 2013 and it has real impact. I still cry every time I watch it. Thanks for all your hard work."

- FB-06-2010-Meredith: "My 2nd-grade son saw the photos a couple months ago and created a presentation...these photos...might get some awareness...He also started bringing home EVERYTHING plastic from his lunch, including the straw from his juice box." 
Figure 1: Picture of the Midway Albatross

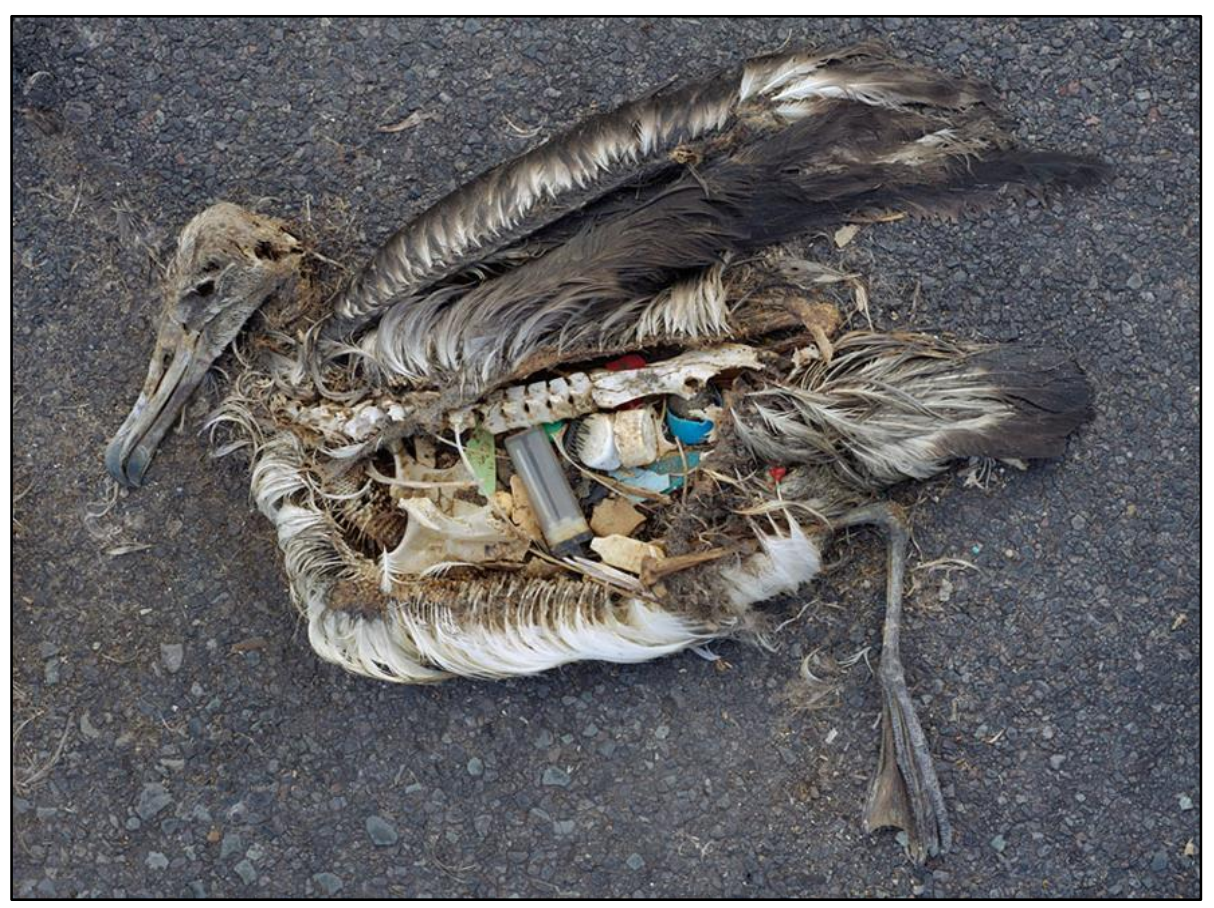

Source: www.chrisjordan.com - reproduced with permission 


\section{Figure 2: Model of Emotion-Symbolic Work}

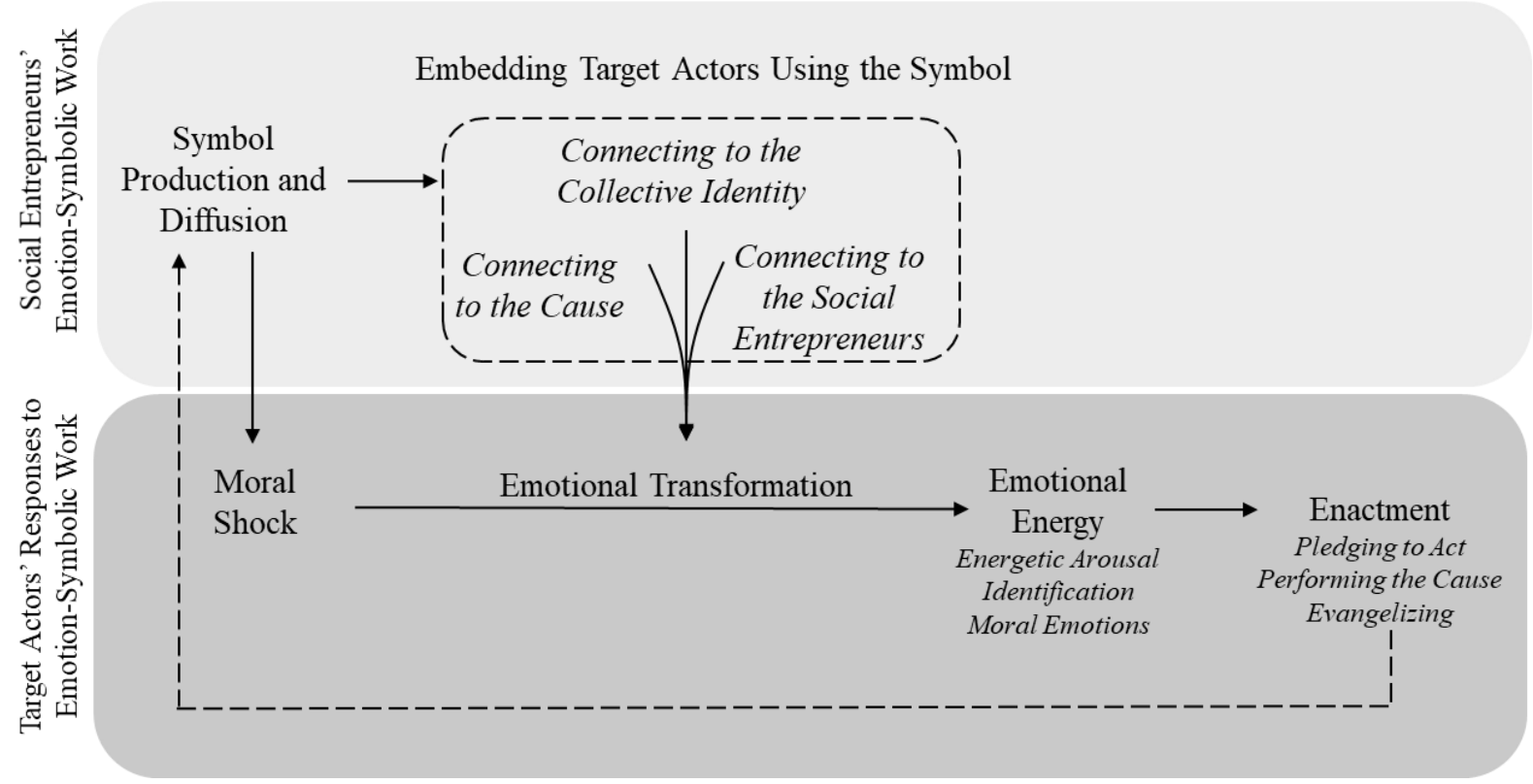




\begin{abstract}
APPENDIX A
To supplement our social media data, and to see whether similar responses could be noted in interactions with the visual symbols and texts that were not mediated by social entrepreneurs, we conducted a keyword search of the terms "Midway", "albatross" and "Chris Jordan", looking for written comments of web users. We found 923 results for videos and 528 results for news items. The Google search relevance algorithm allowed us to focus on video and news webpages with more than occasional comments: one newspaper article and one video clearly stood out with respectively 319 responses for news article and 252 for the video. The article appeared in The Guardian previously to the release of the Albatross documentary ${ }^{4}$ and the video was a YouTube ${ }^{5}$ clip of the film trailer. As mentioned in the main text, the article and the video only showed the problem but did not propose any concrete actions against plastic pollution. Comments were accessed and retrieved on $18^{\text {th }}$ April 2018. We coded comments based on three categories: proposed actions (253 article comments 52 video comments), emotion (101 article comments and 121 video comments) and identification (17 article comments and 6 video comments). We wanted to know whether web users experiencing moral shock that was not mediated by the NPO social entrepreneurs expressed a) their preferences for actions related with individual responsibility, and b) showed identification with a broader movement or a specific organization. We looked for emotional expressions of moral shock (sadness, rage and despair) and for organizational and collective identification in the comments. Different subcategories of solutions emerged from the data.
\end{abstract}

Appendix Table A1 shows the proposed solutions to the problem of plastic pollution given by web users, emotions expressed and signs of identification found in these comments. As explained in the main text, both collective and organizational identification were very rare. Solutions related with individual responsibility were sometimes proposed (11.5\% of the total), although preferences for many other solutions were also expressed.

\title{
Appendix Table A1: Proposed actions, Emotions and Identification in The Guardian Article Comments
}

\begin{tabular}{|l|l|}
\hline Proposed actions & Examples \\
\hline $\begin{array}{l}\text { Better Recycling and } \\
\text { Disposal Systems } \\
(31.06 \%)\end{array}$ & $\begin{array}{l}\text { "plastic does not end up in oceans by itself. We put it there, if it was } \\
\text { disposed of correctly (preferably recycled) then there would be much less of } \\
\text { an issue." }\end{array}$ \\
\hline $\begin{array}{l}\text { Better Policy Initiatives } \\
\text { (taxes, bans...) } \\
(18.31 \%)\end{array}$ & $\begin{array}{l}\text { "Tax them at the going rate - include the environmental costs of their } \\
\text { product in the price" }\end{array}$ \\
\hline $\begin{array}{l}\text { Individual } \\
\text { responsibility/consume } \\
\text { behavior (11.5\%) }\end{array}$ & $\begin{array}{l}\text { "Getting rid of plastic bags is actually pretty easy. My wife and I go around } \\
\text { with cloth bags when we do the shopping and we politely insist on not } \\
\text { being given a plastic bag" }\end{array}$ \\
\hline $\begin{array}{l}\text { Cleaning technologies } \\
\text { and practices (5.33\%) }\end{array}$ & $\begin{array}{l}\text { "Why not scoop it out of the oceans. Surely that should be a central UN } \\
\text { function" }\end{array}$ \\
\hline $\begin{array}{l}\text { New Materials } \\
\text { Technology (5.14\%) }\end{array}$ & $\begin{array}{l}\text { "I think our main hope is in developing biodegradeable products for use } \\
\text { across the planet......but it comes down to the same issue every time...cost" }\end{array}$ \\
\hline $\begin{array}{l}\text { Better practices and } \\
\text { policies in developing } \\
\text { countries (6.52\%) }\end{array}$ & $\begin{array}{l}\text { "The problem is one of waste management in coastal communities of the } \\
\text { developing world. That (and not in expensive campaigns in Europe) is } \\
\text { where resources and energy should be committed." }\end{array}$ \\
\hline $\begin{array}{l}\text { Fostering Awareness } \\
(13.46 \%)\end{array}$ & $\begin{array}{l}\text { "this video is so sad EVERYONE DOWNLOAD IT WITH YOUTUBE } \\
\text { DOWNLOADER AND REPOST IT WE WILL START A } \\
\text { REVOLUTION!" }\end{array}$ \\
\hline Other (8.44\%) & -- \\
\hline & Examples \\
\hline Emotions & \\
\hline
\end{tabular}

${ }^{4} T u r n s$, Anna (2018) Saving the albatross: 'The war is against plastic and they are casualties on the frontline'. The Guardian $12^{\text {th }}$ March https://www.theguardian.com/environment/2018/mar/12/albatross-film-dead-chicks-plastic-savingbirds

${ }^{5}$ IsowerCommunity, When birds eats plastic!!(Shocking video) uploaded $19^{\text {th }}$ February 2013 https://www.youtube.com/watch?v=dAL9Xvrg3hl\&t=3s . 


\begin{tabular}{|l|l|}
\hline Sadness (35.1\%) & "I started to cry in the middle of this. Its so sad 橉 Poor birds \\
\hline Rage (44.35\%) & $\begin{array}{l}\text { "Fine BigOil out of their over bloated profits so they can clean up the Mess } \\
\text { THEY CREATED IN THE FIRST PLACE." }\end{array}$ \\
\hline Guilt (20.55\%) & $\begin{array}{l}\text { "I feel like giving up on my life u killed animals I did it was better when no } \\
\text { houses and all thousands are dieing and some became extinct because of us" }\end{array}$ \\
\hline Identification & Examples \\
\hline Collective (76.96\%) & $\begin{array}{l}\text { "not just 5 people: If you are among those still buying balloons \& } \\
\text { plastics....then you are part of those murders and killers.......Why not join } \\
\text { me and becoming part of the defenders, protectors and part of the solution?" }\end{array}$ \\
\hline $\begin{array}{l}\text { Organizational } \\
(23.04 \%)\end{array}$ & $\begin{array}{l}\text { "I think we are at a good point at the moment to demand that more and } \\
\text { more companies eradicate plastic from their supply chains. As far as food } \\
\text { packaging goes there are alternatives being developed via the Ellen } \\
\text { MacArthur Foundations New Plastics Economy Innovation Prize...." }\end{array}$ \\
\hline
\end{tabular}




\section{ACKNOWLEDGMENTS}

We are very grateful to the deputy editor Marc Gruber and three anonymous reviewers for their thoughtful guidance and insightful comments. We appreciate the detailed feedback from Arturo Álvarez-Roldán, Shaz Ansari, Daniel Beunza, Marina Calvo, Iván Cuesta, Olga Fernández, Raghu Garud, Joel Gehman, Bryant Hudson and Renate Meyer and the generous support of Kellie McElhaney, Mette Morsing and Woody Powell during the course of writing this paper. Earlier versions of this paper were presented at the annual meeting of the Academy of Management in Vancouver (where it was awarded with the Best OMT Entrepreneurship Paper award), the European Group of Organization Studies Colloquium in Naples and Rotterdam, Cornell's SC Johnson College of Business JCB/ILR M\&O Workshop at Cornell University, the Litem Seminar Series at Institut Mines-Télécom Business School in Paris, KIN Center for Digital Innovation and Department of Organization Science at VU University Amsterdam, Grenoble Ecole de Management, IESEG School of Management, Instituto Interuniversitario López Piñero and Llibrería Ramón Llull in Valencia. We thank all the participants for their comments and suggestions. Any inaccuracies or omissions are entirely our own. 


\section{BIOGRAPHIES}

David Barberá-Tomás (jobarto@ingenio.upv.es) is associate professor in INGENIO (CSIC-UPV), Universitat Politécnica de Valencia and Department of Engineering Projects (UPV). He received his PhD in Universitat Politécnica de Valéncia. His research uses insights from organizational and innovation studies to study different domains related with entrepreneurship and innovation.

Itziar Castello (i.castello@surrey.ac.uk) is associate professor in Digital Economy at Surrey Business School, University of Surrey. She earned her PhD from ESADE, Ramon Llull University. Her research uses institutional theory, corporate social responsibility, social movement studies and entrepreneurship theories to analyze discourses of legitimation and social change.

Frank G.A. de Bakker (f.debakker@ieseg.fr) is professor of corporate social responsibility at IESEG School of Management and a member of the research laboratory Lille Economics Management (LEM-CNRS 9221). He received his $\mathrm{PhD}$ from the University of Twente. In his research he combines insights from institutional theory, social movement studies and stakeholder theory to examine interactions between activist groups and business firms on issues of corporate social responsibility.

Charlene Zietsma (Charlene.Zietsma@psu.edu) is associate professor of management at the Smeal College of Business, Penn State University. She earned her PhD from the University of British Columbia. Her research uses theories of institutions, social movements, and entrepreneurs to investigate the agency and processes involved in social change. 